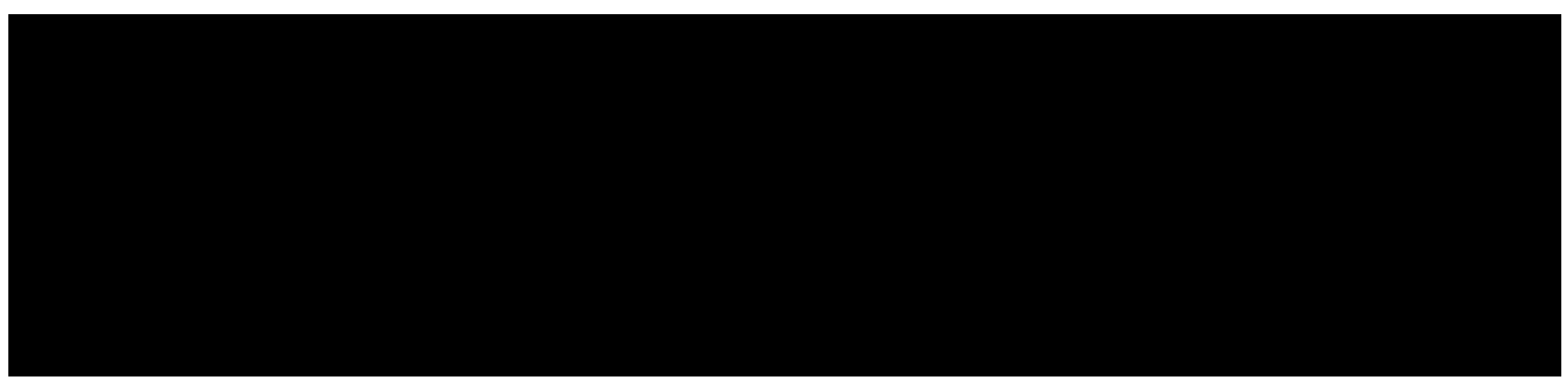

Invited review

\title{
Tuberculosis: The drug development pipeline at a glance
}

\author{
Baptiste Villemagne ${ }^{a, b, c, d, e}$, Céline Crauste ${ }^{a, b, c, d, e}$, Marion Flipo $^{\text {a,b,c,d,e }}$, \\ Alain R. Baulard ${ }^{\text {a,c,d,e,f,g,h }}$, Benoit Déprez ${ }^{\text {a,b,c,d,e,* }}$, Nicolas Willand ${ }^{\text {a,b,c,d,e }}$ \\ ${ }^{a}$ Univ Lille Nord de France, F-59000 Lille, France \\ b INSERM U761, Biostructures and Drug Discovery, F-59000 Lille, France \\ ${ }^{\mathrm{c}}$ UDSL, F-59000 Lille, France \\ d IPL, F-59019 Lille, France \\ e PRIM, F-59000 Lille, France \\ ${ }^{\mathrm{f}}$ INSERM U1019, F-59000 Lille, France \\ ${ }^{g}$ CNRS UMR8204, F-59021 Lille, France \\ ${ }^{\mathrm{h}}$ Center for Infection and Immunity of Lille, F-59019 Lille, France
}

\section{A R T I C L E I N F O}

\section{Article history:}

Received 4 January 2012

Received in revised form

15 February 2012

Accepted 16 February 2012

Available online 25 February 2012

\section{Keywords:}

Mycobacterium tuberculosis

Drug discovery and drug development

New molecular entities

\begin{abstract}
A B S T R A C T
Tuberculosis is a major disease causing every year 1.8 million deaths worldwide and represents the leading cause of mortality resulting from a bacterial infection. Introduction in the 60's of first-line drug regimen resulted in the control of the disease and TB was perceived as defeating. However, since the progression of HIV leading to co-infection with AIDS and the emergence of drug resistant strains, the need of new anti-tuberculosis drugs was not overstated. However in the past 40 years any new molecule did succeed in reaching the market. Today, the pipeline of potential new treatments has been fulfilled with several compounds in clinical trials or preclinical development with promising activities against sensitive and resistant Mycobacterium tuberculosis strains. Compounds as gatifloxacin, moxifloxacin, metronidazole or linezolid already used against other bacterial infections are currently evaluated in clinical phases 2 or 3 for treating tuberculosis. In addition, analogues of known TB drugs (PA-824, OPC67683, PNU-100480, AZD5847, SQ609, SQ109, DC-159a) and new chemical entities (TMC207, BTZ043, DNB1, BDM31343) are under development. In this review, we report the chemical synthesis, mode of action when known, in vitro and in vivo activities and clinical data of all current small molecules targeting tuberculosis.
\end{abstract}

(c) 2012 Elsevier Masson SAS. All rights reserved.
Abbreviations: $\mathrm{Ac}_{2} \mathrm{O}$, acetic anhydride; AcOEt, ethyl acetate; BINAP, 2,2'-bis(diphenylphosphino)-1,1'-binaphthyl; Boc, tert-butyloxycarbonyl; Cbz, carboxybenzyl; CFU, colony forming unit; DBU, 1,8-diazabicyclo[5.4.0]undec-7-ene; DCM dichloromethane; Ddn, deazaflavin-dependent nitroreductase; DHP, 2,3dihydropyran; DIEA, diisopropylethylamine; DMF, dimethylformamide; DOTS, directly observed treatment short-course; EBA, early bactericidal activity; EDCI, Nethyl-3-(3-dimethylaminopropyl)carbodiimide; EMB, ethambutol; ETH, ethionamide; $\mathrm{EtOH}$, ethanol; HBTU, O-benzotriazole- $\mathrm{N}, \mathrm{N}, \mathrm{N}^{\prime}, \mathrm{N}^{\prime}$-tetramethyluronium hexafluorophosphate; HOBt, N-hydroxybenzotriazole; INH, isoniazid; LDA, lithium diisopropylamide; MBD, minimal bactericidal dose; MDR, multidrug resistant; $\mathrm{MeCN}$, acetonitrile; MED, minimal effective dose; $\mathrm{MeOH}$, methanol; Ms, mesyl; MIC, minimal inhibitory concentration; MXF, moxifloxacin; TBS, tert-butyldimethylsilyl; pTsOH, p-toluenesulfonic acid; PZA, pyrazinamide; QR, quinolone resistant; RIF, rifampin; TB, tuberculosis; TEA, triethylamine; THF, tetrahydrofuran; WHO, world health organization; XDR, extensively drug resistant.

* Corresponding author. Faculté de Pharmacie, Univ Lille Nord de France, 3 rue du Pr Laguesse, BP 83, Lille F-59006, France. Tel.: +33 320964 947; fax: +33 320964 709.

E-mail address: benoit.deprez@univ-lille2.fr (B. Déprez).

URL: http://www.deprezlab.fr, http://www.drugdiscoverylille.org

\section{Introduction}

In 2011, tuberculosis (TB) remained the second cause of death from infectious disease worldwide. It mainly affects the poorest countries of Africa and Southeast Asia. In 2010, according to the World Health Organization (WHO), TB incidence and prevalence were estimated at 8.8 and 12 million cases respectively. 1.1 million among HIV-negative people and 0.35 million among HIV-positive people died from TB in the same year [1]. Most importantly, one third of the world population is infected with latent infection and $10 \%$ of those infected people will develop active TB in their life. The agent responsible for this burden is Mycobacterium tuberculosis. Bacteria are spread through the air by active TB patients and most commonly affect the lungs. The major obstacles to the global control of this infectious disease include the difficulties to detect and cure a sufficient number of cases to interrupt transmission [2]. Several drugs have been developed for controlling TB, curing the patient and preventing further transmission of the disease. The 
directly observed treatment short-course (DOTS), a multidrug therapy program developed by WHO, is one of the most efficient weapons against the global TB epidemic. Nevertheless, the treatment success rate struggles to reach the target of $85 \%[3,4]$. Unfortunately, first-line treatment can fail due to poor compliance which leads to the emergence of multidrug resistant (MDR) strains of M. tuberculosis. In 2010, the number of MDR-TB infections was estimated at 650,000 cases (5.4\% of the global infected population) [1]. MDR-TB must be treated for 2-4 years with second-line drugs. These drugs are less effective and often associated with serious side effects, which reduce patients' compliance and thus lead to high rates of recurrence, appearance of extensively drug resistant (XDR) strains and mortality. In 2010, 58 countries reported at least one case of XDR-TB. All these data highlight the importance for the discovery of alternative therapies that could improve treatment of both sensitive and resistant TB.

Anti-tuberculosis agents in current development trigger a large panel of biological pathways such as cell wall synthesis, protein synthesis or membrane energy production [5]. The number of TB drugs in preclinical and clinical development is today higher than during the past 40 years. In this article we review all small chemical entities ( $\mathrm{MW}<600 \mathrm{~g} / \mathrm{mol}$ ) currently in clinical trials and we briefly describe some promising strategies that are in preclinical development (Fig. 2).

\section{Current therapies}

Most of the drugs which composed the arsenal of the first-line TB treatment were discovered during the 1950's and the 60's (Fig. 1). In 1944, streptomycin was the first compound used to treat TB. [6]. This aminoglycoside interferes with protein biosynthesis through an interaction with the small 30 S subunit of the ribosome $[7,8]$. The discovery of para-aminosalicylic acid in 1946 was quickly followed by the important identification of isoniazid (INH) [9], one of the most active anti-TB drug used today. Mechanisms of action for both compounds were unknown during their development, and the target of para-aminosalicylic acid is still the subject of investigations [10]. Inhibition of mycolic acids biosynthesis, one of the essential components of the mycobacterial cell wall was determined as isoniazid mechanism of action [11,12]. Pyrazinamide (PZA) appeared as a potential TB drug in 1952 [13]. Its introduction in the TB treatment in the 1980s was a great success as it allowed to shorten the duration of the TB therapy from 9 to 6 months. Despite an important similarity of structures between isoniazid and pyrazinamide, their mechanisms of action are totally different. Pyrazinamide activity is dependent on pyrazinoic acid release, which causes intake of proton and dysfunction of the $\mathrm{pH}$ balance of mycobacteria $[14,15]$. It has been recently shown that pyrazinoic acid targets the ribosomal protein S1, an essential protein involved in the ribosome-sparing process of transtranslation [16].

Ethambutol (EMB) and rifampin (RIF), the two last derivatives used in the TB first-line treatment, were discovered during the 60's. Ethambutol is an ethylenediamine discovered in 1961 [17], which affects the cell wall by specifically targeting the polymerization of arabinogalactane and lipoarabinomannane [18]. Finally, rifampin appeared as a drug of choice for TB treatment [19,20] around 1970, by acting on replicating and non-replicating mycobacteria. This derivative belongs to the rifamycine family and inhibits bacterial RNA synthesis by binding to the $\beta$-subunit of the DNA-dependent polymerase [21].

Despite the efficiency of the drugs alone, a significant improvement of the treatment was obtained with combined therapy in order to limit the apparition of resistant strains. Today, the current standard regimen (DOTS) for TB recommended by WHO is a combination of isoniazid, rifampin, ethambutol and pyrazinamide for a 6 months therapy.

To treat MDR-TB, WHO recommends the use of second-line drugs which include aminoglycosides (kanamycin, amikacin), capreomycin, cycloserin, para-aminosalicylic acid, thioamides (ethionamide (ETH), prothionamide), and fluoroquinolones (ciprofloxacin, ofloxacin, levofloxacin). Ethionamide and prothionamide are isoniazid analogues discovered in 1956 [22]. As isoniazid, they target mycolic acids biosynthesis through the inhibition of InhA

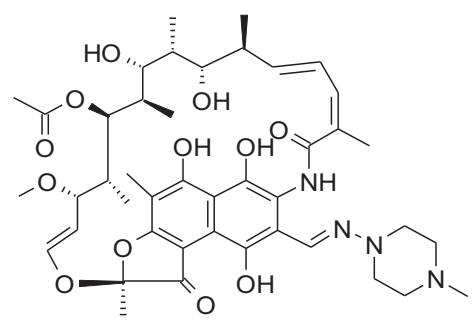

Rifampin<smiles>NNC(=O)c1ccncc1</smiles>

Isoniazid<smiles>NC(=O)c1cnccn1</smiles>

Pyrazinamide<smiles>CCC(CO)NCCNC(CC)CO</smiles>

Ethambutol

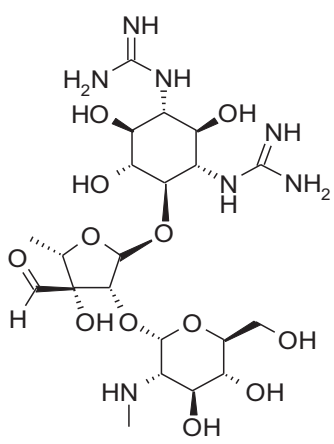

Streptomycin<smiles>Nc1ccc(C(=O)O)c(O)c1</smiles>

Para-aminosalicylic acid<smiles>NC1CONC1=O</smiles><smiles>CC1COc2c(N3CCN(C)CC3)c(F)cc3c(=O)c(C(=O)O)cn1c23</smiles>

Levofloxacin<smiles>CCc1cc(C(N)=S)ccn1</smiles>

Ethionamide

Fig. 1. Structures of anti-tuberculosis drugs. 


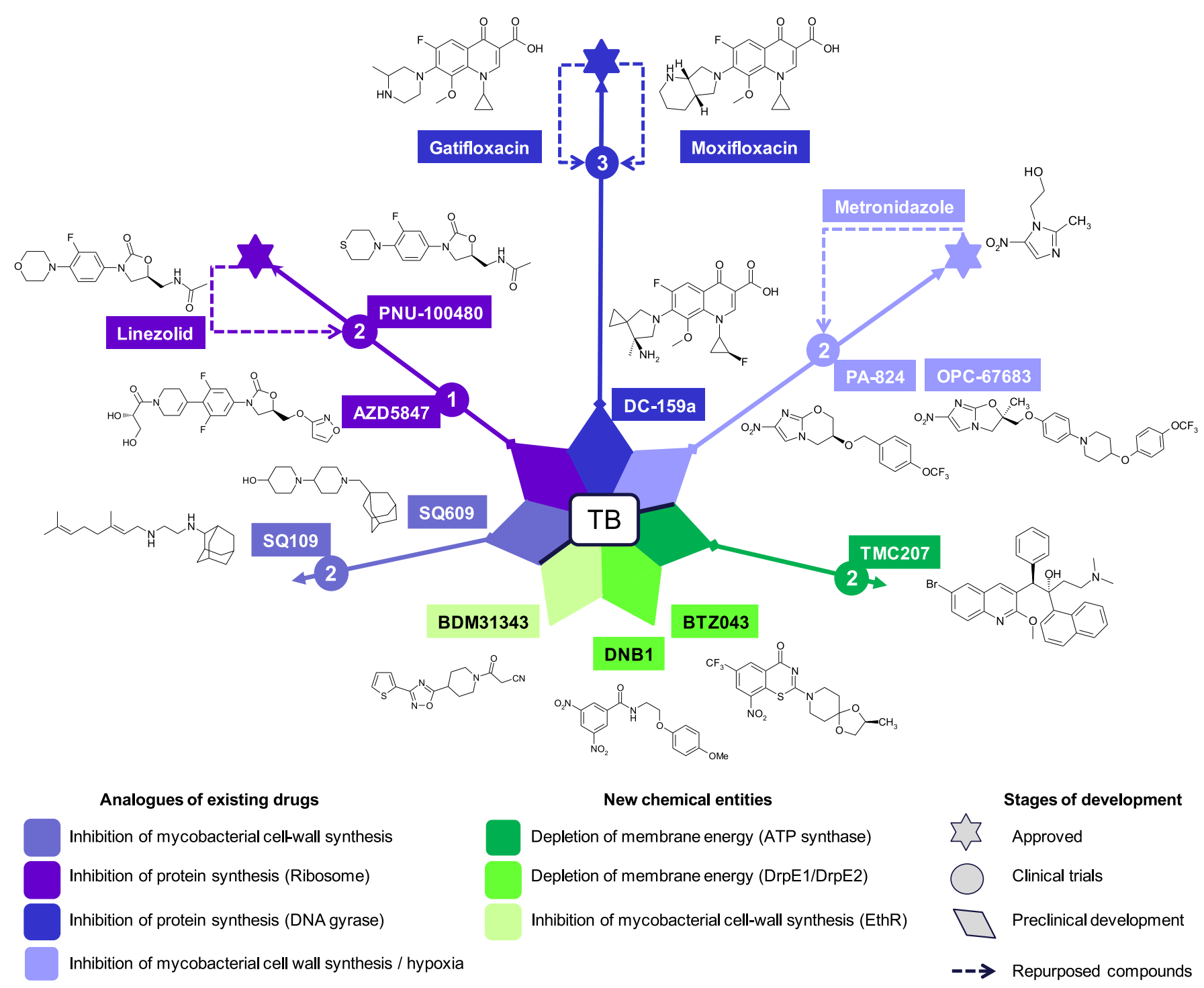

Fig. 2. Antitubercular compounds in development and their targets.

[23]. Isoniazid and the two thioamides analogues are prodrugs that respectively require bioactivation by two distinct proteins: KatG and EthA [24-26]. D-cycloserine, another cell wall inhibitor, was discovered in 1969 [27]. This compound triggers peptidoglycan synthesis through D-alanine racemase and D-alanine ligase inhibition $[28,29]$. In the mean time, aminoglycosid analogues (kanamycin, amikacin) [30] and cyclic peptide analogues (viomycin, capreomycin) of streptomycin were reported. These compounds target the small subunit $30 \mathrm{~S}$ of the ribosome [5]. The most recent anti-TB drugs are fluoroquinolones that derived from nalidixic acid, discovered in the early 60's for its antibacterial activity [31]. Among all the antibacterial fluoroquinolones developed, ciprofloxacin, ofloxacin and levofloxacin are the most widely used in anti-TB treatments [32]. In mycobacteria, fluoroquinolones target the DNA gyrase, which is the sole type II topoisomerase in this organism [33-35].

\section{Global portfolio of clinical candidates}

In this review we present advances that have been made over the last 10 years, with TB drugs that have entered clinical trials (Fig. 2). Fluoroquinolones gatifloxacin and moxifloxacin (Phase 3), oxazolidinone linezolid and nitroimidazole metronidazole (Phase 2) have been repurposed for tuberculosis. New chemical entities have also progressed in clinical development based on optimization of known chemical scaffolds: this is the case for nitroimidazole derivatives OPC-67683 and PA-824 both in phase 2, substituted ethylenediamine SQ109 (phase 2), oxazolidinone analogues PNU100480 (phase 2) and AZD5847 (phase 1). Finally, promising diarylquinoline TMC207, first compound of a new class of antituberculosis drugs is currently evaluated in Phase 2. We also highlight promising strategies currently in preclinical trials that not only proposed new potent chemical anti-tuberculosis scaffold but also new biological targets. We discuss every strategy and molecule on the basis of their development stage, starting from phase 3 to end up with preclinical developments.

\subsection{Compounds in phase 3 clinical trials: fluoroquinolones}

Structure, mode of action and calculated physico-chemical properties [36] of compounds in phase 3 clinical trials are reported in Table 1.

The fluoroquinolones gatifloxacin and moxifloxacin (Table 1) were marketed in 1999 for the treatment of respiratory tract 
Table 1

Structures and calculated physico-chemical properties of compounds in phase 3 clinical trials [36].

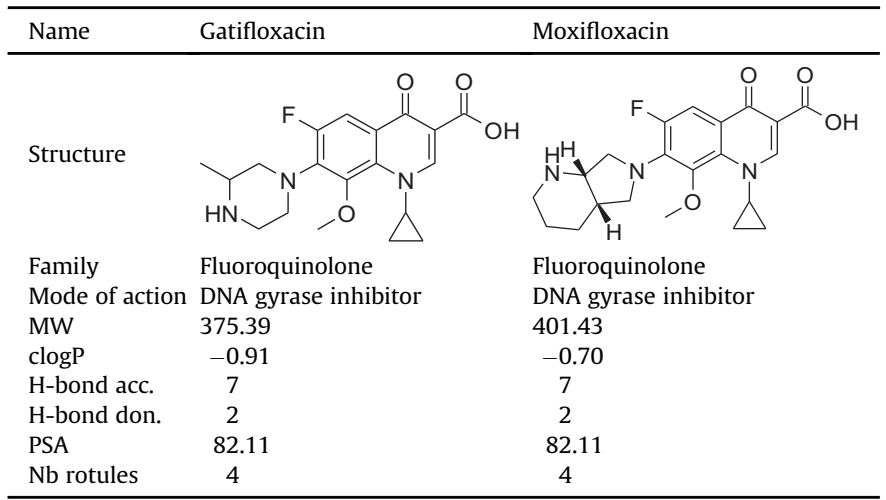

infections. These two molecules are currently in phase 3 clinical trials for the treatment of TB [37].

\subsubsection{Chemical synthesis}

The quinolone ring is obtained in a 4-steps procedure from 2,4,5-trifluoro-3-methoxybenzoyl chloride (Fig. 3) [38]. The substitution with the appropriate secondary amine followed by the hydrolysis of the ethyl ester leads to gatifloxacin and moxifloxacin [39].

\subsubsection{Target and mechanism of action}

M. tuberculosis does not possess any type IV topoisomerase. Thus, fluoroquinolones target specifically the mycobacterial topoisomerase II DNA gyrase. This implies that large spectra fluoroquinolones suffer from suboptimal inhibition of topoisomerase II and thus can be improved [35].

\subsubsection{In vitro activity against $M$. tuberculosis}

Gatifloxacin and moxifloxacin have better in vitro activity against $M$. tuberculosis than the older fluoroquinolones ciprofloxacin and ofloxacin [40]. MIC against M. tuberculosis H37Rv is
$0.12-0.25 \mu \mathrm{g} / \mathrm{mL}$ for gatifloxacin and $0.18-0.5 \mu \mathrm{g} / \mathrm{mL}$ for moxifloxacin $[35,41,42]$. Gatifloxacin has a slightly better activity against $M$. tuberculosis clinical isolates (23 strains) than moxifloxacin. Indeed, the range of $\mathrm{MIC}_{90}$ is $0.007-0.12 \mu \mathrm{g} / \mathrm{mL}$ for gatifloxacin and $0.031-0.12 \mu \mathrm{g} / \mathrm{mL}$ for moxifloxacin [43].

\subsubsection{In vivo efficacy in mice}

In a murine model of TB, gatifloxacin $(100 \mathrm{mg} / \mathrm{kg})$, moxifloxacin $(100 \mathrm{mg} / \mathrm{kg})$ and isoniazid $(25 \mathrm{mg} / \mathrm{kg}$ ) had similar activities after a 4 weeks treatment [43]. In mice infected with M. tuberculosis by inhalation, replacement of isoniazid $(25 \mathrm{mg} / \mathrm{kg}$ ) with moxifloxacin (100 $\mathrm{mg} / \mathrm{kg}$ ) in the standard RIF/INH/PZA 6 months regimen shortened the duration of therapy by up to 2 months and no relapse was observed 3 months after the end of the treatment [44]. However this result was not confirmed by Ibrahim and colleagues in intravenously infected mice [45]. Substitution of moxifloxacin for rifampin was deleterious and after 6 months of treatment without rifampin, mice were still culture positive [46].

In mice intranasally infected, gatifloxacin was evaluated alone and in addition with ethionamide, pyrazinamide and ethambutol. The best reduction of the CFU counts in the lungs after 4 weeks of treatment was obtained with the combination of ethionamide (75 mg/kg) and gatifloxacin (100 mg/kg) [43].

\subsubsection{Phase 1}

In healthy volunteers, moxifloxacin and gatifloxacin showed a high bioavailability (90\% and $96 \%$ respectively) [47,48]. After a single oral dose of $400 \mathrm{mg}$, a maximum plasma concentration $\left(C_{\max }\right)$ of $4.3 \mu \mathrm{g} / \mathrm{mL}$ for moxifloxacin and $3.4 \mu \mathrm{g} / \mathrm{mL}$ for gatifloxacin was reached in $1.0 \mathrm{~h}$ and $1.5 \mathrm{~h}$, respectively. The half-life was $9.1 \mathrm{~h}$ for moxifloxacin and $6.5 \mathrm{~h}$ for gatifloxacin and AUC were respectively 39 and $30 \mu \mathrm{g} \mathrm{h} / \mathrm{mL}$ [49].

\subsubsection{Phase 2}

In TB patients, moxifloxacin and gatifloxacin at $400 \mathrm{mg}$ once daily have good early bactericidal activities (EBA) from day 0 to day 2 ( 0.33 and $0.35 \log \mathrm{CFU} / \mathrm{mL} /$ day respectively) but less than isoniazid at $300 \mathrm{mg}$ (0.67 $\log \mathrm{CFU} / \mathrm{mL} /$ day) [50]. Another study showed that the EBA of a 5 day-monotherapy with moxifloxacin $(400 \mathrm{mg}$ daily) is comparable to that of isoniazid (6 mg/ $\mathrm{kg}$ once daily) [51].<smiles>CCOC=C(C(=O)OCC)C(=O)c1cc(F)c(F)c(OC)c1F</smiles>

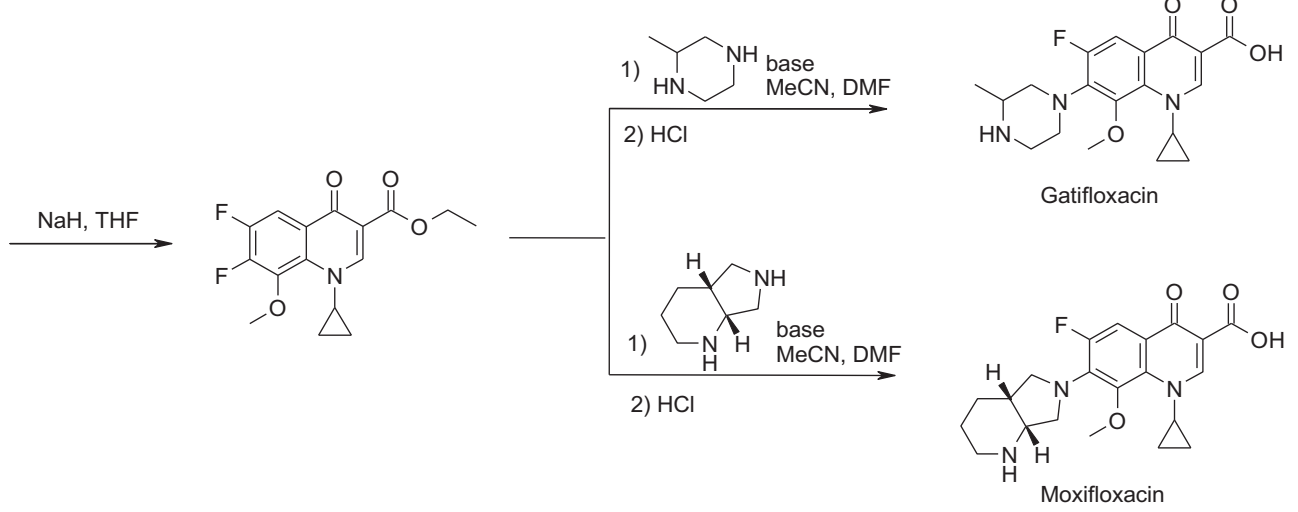

Fig. 3. Synthetic pathways for gatifloxacin and moxifloxacin. 
In a phase $2 \mathrm{~b}$ study, addition of moxifloxacin to the standard regimen (RIF/INH/PZA/EMB) in the first two months shortened the time to culture conversion and led to a higher culture conversion rate after 6 weeks of treatment (82\% in the moxifloxacin group compared to $61 \%$ in the standard regimen group) [52]. Substitution of moxifloxacin for isoniazid in the standard regimen did not significantly increase the culture negativity of patients after 8 weeks of therapy [53]. However replacement of ethambutol with moxifloxacin or gatifloxacin in the standard regimen significantly improved culture conversion after 8 weeks of treatment and might shorten tuberculosis therapy [54,55].

\subsubsection{Safety and tolerability}

Moxifloxacin was safe and well tolerated in a long-term administration at $400 \mathrm{mg}$ once daily [56]. The main side effects observed with moxifloxacin and gatifloxacin were headache and gastrointestinal disturbances $[47,48]$. No additional adverse events were observed when ethambutol was replaced with moxifloxacin or gatifloxacin in the standard regimen [55].

\subsubsection{Current advances}

Gatifloxacin and moxifloxacin are currently being evaluated in a phase 3 clinical trials. The aim of these studies is to evaluate the efficacy and safety of gatifloxacin and moxifloxacin and the possibility of reducing the duration of tuberculosis therapy from six to four months $[57,58]$.

\subsection{Compounds in phase 2 clinical trials}

Structure, mode of action and calculated physico-chemical properties [36] of compounds in phase 2 clinical trials are reported in Table 2.

\subsubsection{Diarylquinoline: TMC207}

TMC207 (R207910, Bedaquiline) is a novel diarylquinoline belonging to a new class of anti-tuberculosis drugs (Table 2). This compound was discovered by Johnson \& Johnson through a wholecell-screening on Mycobacterium smegmatis and it is currently clinically developed by Tibotec in collaboration with the TB alliance.

3.2.1.1. Chemical synthesis. TMC207 is synthesized in five steps from 3-phenylpropionic acid and para-bromoaniline. The quinoline ring is obtained thanks to a Vilsmeier-Haack reaction and the final condensation leads to four stereoisomers that are separated by column chromatography over silica gel and then by chiral chromatography to yield the desired (R,S) compound (Fig. 4) [59,60].

3.2.1.2. Target and mechanism of action. TMC207 inhibits the proton transfer chain of the mycobacterial ATP synthase [61]. The mechanism of action of the diarylquinoline was originally proposed after isolation of mutant strains of M. tuberculosis and M. smegmatis that were resistant to TMC207. Their genomes were sequenced and compared to susceptible strains [62]. The only common mutation was localized in the atpE gene encoding for subunit c of ATP synthase which was further validated as the compound's precise target [63]. TMC207 is not active on human mitochondrial ATP synthase [64]. Whereas derived from quinolones, TMC207 has no inhibitory effect on the DNA gyrase of $M$. tuberculosis.

3.2.1.3. In vitro activity against $M$. tuberculosis. TMC207 is a potent agent against $M$. tuberculosis $\mathrm{H} 37 \mathrm{Rv}$ with a $\mathrm{MIC}_{99}$ equal to $0.030 \mu \mathrm{g} /$ $\mathrm{mL}$ and against a range of $M$. tuberculosis clinical isolates with MIC between 0.030 and $0.120 \mu \mathrm{g} / \mathrm{mL}$ (tested on 6 susceptible strains). TMC207 has a similar efficacy against sensitive and resistant $M$. tuberculosis strains ( $\mathrm{MIC}=0.003-0.120 \mu \mathrm{g} / \mathrm{mL}$ ) [62]. Interestingly, TMC207 is reported to be active against dormant mycobacteria [65].

Table 2

Structures and calculated physico-chemical properties of compounds in phase 2 clinical trials [36].

\begin{tabular}{|c|c|c|c|}
\hline Name & TMC207 & PA-824 & OPC-67683 \\
\hline \multicolumn{4}{|l|}{ Structure } \\
\hline Family & Diarylquinoline & Nitroimidazole & Nitroimidazole \\
\hline Mode of action & ATP synthase inhibitor & Cell wall synthesis inhibitor & Cell wall synthesis inhibitor \\
\hline MW & 555.50 & 359.26 & 534.48 \\
\hline $\operatorname{clog} \mathrm{P}$ & 6.93 & 4.30 & 6.45 \\
\hline H-bond acc. & 4 & 6 & 8 \\
\hline H-bond don. & 1 & 0 & 0 \\
\hline PSA & 45.59 & 91.33 & 103.79 \\
\hline $\mathrm{Nb}$ rotules & 8 & 6 & 9 \\
\hline Name & SQ109 & Linezolid & PNU-100480 \\
\hline \multicolumn{4}{|l|}{ Structure } \\
\hline Family & Diamine derivatives & Oxazolidinone & Oxazolidinone \\
\hline Mode of action & Cell wall synthesis inhibitor & Protein synthesis inhibitor & Protein synthesis inhibitor \\
\hline MW & 330.55 & 337.34 & 353.41 \\
\hline $\operatorname{clog} \mathrm{P}$ & 4.94 & 0.894 & 1.64 \\
\hline H-bond acc. & 2 & 5 & 5 \\
\hline H-bond don. & 2 & 1 & 1 \\
\hline PSA & 24.06 & 71.1 & 87.2 \\
\hline $\mathrm{Nb}$ rotules & 9 & 4 & 4 \\
\hline
\end{tabular}



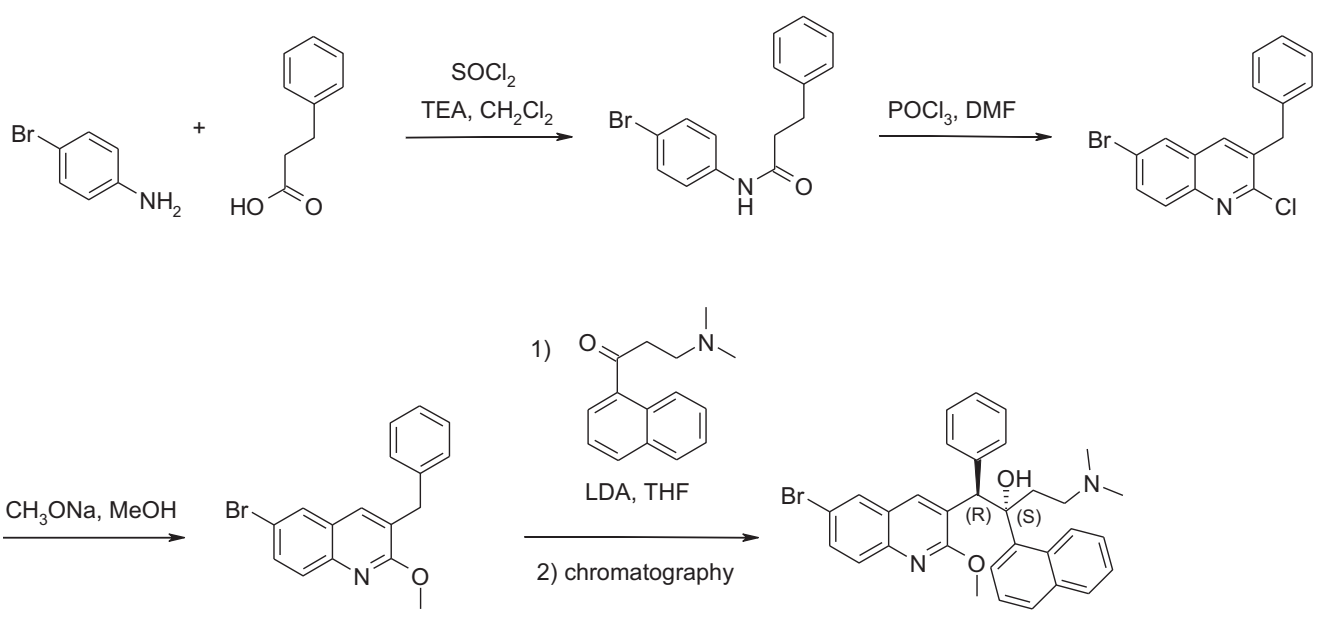

Fig. 4. Synthetic pathway for TMC207.

3.2.1.4. In vivo efficacy in mice. In the nonestablished infection murine model of TB, a single dose of TMC207 at $50 \mathrm{mg} / \mathrm{kg}$ led to a bacteriostatic effect for 8 days whereas administration of $100 \mathrm{mg} / \mathrm{kg}$ resulted in a bactericidal effect for the same period of time [62]. In the same mouse model, TMC207 $(12.5 \mathrm{mg} / \mathrm{kg})$ was more active than isoniazid $(25 \mathrm{mg} / \mathrm{kg})$ after 4 weeks of treatment.

In the established infection model, TMC207 (25 mg/kg) was more efficacious than rifampin alone $(10 \mathrm{mg} / \mathrm{kg})$ and as active as the first-line regimen (RIF/INH/PZA). Addition of TMC207 (25 mg/ $\mathrm{kg}$ ) to this regimen improved culture conversion after 4 and 8 weeks of treatment [62]. It was also demonstrated that supplementation of TMC207 $(25 \mathrm{mg} / \mathrm{kg})$ to the first-line regimen or substitution of TMC207 for isoniazid in this regimen could shorten the treatment duration from 6 to 4 months [45]. Indeed mice treated with these combinations were culture negative after 4 months of therapy and the relapse rate 3 months after the end of the treatment was similar to that of mice treated for 6 months with the first-line regimen $(6 \%, 13 \%$ and $17 \%$ respectively). However TMC207 could not replace rifampin [45].

A combination of TMC207 with the WHO recommended MDR$\mathrm{TB}$ regimen (amikacin/ETH/MXF/PZA) resulted in negative cultures in a drug-sensitive mouse model after two months of treatment [66], whereas without TMC207, 9 months of therapy were necessary to render both spleens and lungs culture negative [67]. After 6 months of treatment with the MDR-TB regimen the relapse rate 3 months after the end of the therapy was 58\% and $28 \%$ when TMC207 was added to this regimen [68].

3.2.1.5. Phase 1. Pharmacokinetic study in healthy volunteers showed that after single oral administrations ranging from 10 to $700 \mathrm{mg}$, the maximum plasma concentration $\left(C_{\max }\right)$ were reached at $5 \mathrm{~h}$. $C_{\max }$ and AUC were proportional to dose at the contrary of the half-life. The $C_{\max }$ varied from $0.07 \mu \mathrm{g} / \mathrm{mL}$ for a single oral dose of $10 \mathrm{mg}$ to $9 \mu \mathrm{g} / \mathrm{mL}$ for a dose of $400 \mathrm{mg}$. [62]. After once daily doses for 14 days the $A_{U C} C_{0-24 h}$ values at steady state were 7.9, 24 and $52 \mu \mathrm{g} \mathrm{h} / \mathrm{mL}$ with dose of 50,150 and $400 \mathrm{mg} /$ day respectively. CYP3A4 was identified as responsible for TMC207 oxidative metabolism and coadministration of rifampin in healthy volunteers led to a decrease of TMC207 AUC by 50\% [69].

3.2.1.6. Phase 2. In an EBA study, recruited patients with drug susceptible pulmonary TB received once daily oral doses of TMC207 $(25 \mathrm{mg}, 100 \mathrm{mg}$ or $400 \mathrm{mg})$ or rifampin $(600 \mathrm{mg})$ or isoniazid (300 mg) for 7 days. Whereas TMC207 at $25 \mathrm{mg}$ and $100 \mathrm{mg}$ had no bactericidal effect, the decreases of bacterial load in $\log \mathrm{CFU} / \mathrm{mL}$ from day 0-7 were 0.77 for TMC207 at $400 \mathrm{mg}, 1.88$ for isoniazid and 1.70 for rifampin. The bactericidal effect was observed later in patients treated with $400 \mathrm{mg}$ of TMC207 than in the group receiving isoniazid or rifampin, however it was of similar magnitude on days 4-7 [70].

In a phase $2 \mathrm{~b}$ study, MDR-TB patients received either TMC207 (400 mg daily for 2 weeks, followed by $200 \mathrm{mg}$ three times a week) or placebo in combination with 5 second-line drugs. After 8 weeks of treatment, TMC207 increased the proportion of sputum culture conversion from $9 \%$ to $48 \%$ [71]. After 24 weeks of treatment, addition of TMC207 resulted in a faster culture conversion and a higher sputum conversion rate compared to placebo (79\% vs 58\%) [72].

3.2.1.7. Safety and tolerability. TMC207 was well tolerated. During the EBA study no serious adverse events occurred [70]. In MDR-TB patients treated for 2 months with TMC207 the majority of adverse events were mild to moderate and only nausea occurred more frequently than in placebo group (26\% vs $4 \%$ ) [71].

3.2.1.8. Current advances. TMC207 is expected to enter phase 3 clinical trial in 2012 to provide early access of TMC207 to patients with XDR and Pre-XDR-TB [73].

\subsubsection{Nitroimidazoles}

3.2.2.1. Metronidazole. Metronidazole (Fig. 5), developed in the 1960 's, is currently marketed to treat protozoa and anaerobic bacteria infections. Because of its preferential activity against anaerobic organisms [74,75], metronidazole was considered as an attractive compound to treat non-replicating M. tuberculosis. In 1999 Brooks et al. demonstrated that metronidazole exhibited only modest activity on in vitro and in vivo models, alone or combined with isoniazid [76]. Currently, a phase 2 study driven by the National Institute of Allergy and Infectious Diseases (NIAID) in

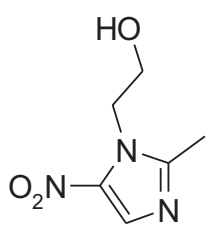

Fig. 5. Structure of metronidazole. 
South Korea is exploring the impact of adding metronidazole to the standard second-line drug regimen [77].

3.2.2.2. PA-824. Initially, bicyclic nitroimidazofurans were investigated as potential radiosensitizing agents for use in cancer radiotherapy [78] but were also found to display some antitubercular activities in both in vitro and in vivo models $[79,80]$. Very promising results were obtained for the lead compound of this chemical series, CGI 17341 (Fig. 6), but associated mutagenicity discouraged further research with this compound. Nevertheless, the strong activities obtained with these compounds suggested that the bicyclic nitroimidazole moiety might be an interesting pharmacophore. Based on this observation, a chemical library of 328 nitroimidazopyrans $[81,82]$ was designed and evaluated on $M$. tuberculosis. One member, PA-824 (Table 2), was identified as a promising antitubercular agent.

3.2.2.2.1. Chemical synthesis. The synthesis of PA- 824 published in the original patent, requires 5 linear steps, starting from 2,4dinitroimidazole (Fig. 7) which is first alkylated on N-1. Then cyclization affords the nitroimidazopyran fused ring which is converted to PA-824 after alkylation with 1-(bromomethyl)-4-(trifluoromethoxy)benzene [81].

3.2.2.2.2. Target and mechanism of action. PA- 824 is bioreduced by the deazaflavin $\mathrm{F}_{420}$ dependent glucose-6-phosphate dehydrogenase (FGD1) and a deazaflavin-dependent nitroreductase Rv3547 (Ddn) $[83,84]$. PA-824 is active against M. tuberculosis in both aerobic and hypoxic conditions [82]. Both activities are supposed to be mediated by two different mechanisms of actions [85]. Stover et al. [82] showed that PA-824 inhibits the biosynthesis of mycolic acids in a dose-dependent manner. Singh et al. [85] demonstrated that activity of PA-824 analogues in anaerobic conditions was correlated with the formation of the des-nitro metabolite and the concomitant release of NO. This data was confirmed by a study published in 2009 by Manjunatha et al. [86] where activity of PA824 was comparable to the activity of respiratory poisons like cyanide. This activity was highlighted by a dramatic drop in intracellular ATP in a dose and time-dependent manner attributed to the inhibition of cytochrome $c$ oxidase by NO released.

3.2.2.2.3. In vitro activity against $M$. tuberculosis. The activity of PA-824 is highly specific to the M. tuberculosis complex [82]. PA824 has similar MIC against drug-sensitive, mono-resistant, poly-resistant and MDR-TB. The MIC against M. tuberculosis H37Rv is $0.039-0.13 \mu \mathrm{g} / \mathrm{mL}[82,87-89]$. The MIC against drug-sensitive M. tuberculosis (12 clinical isolates) is $0.06-0.25 \mu \mathrm{g} / \mathrm{mL}$ [82] and against mono, poly or multidrug resistant $M$. tuberculosis (21 clinical isolates) the MIC is $0.015-0.531 \mu \mathrm{g} / \mathrm{mL}[82,87]$. These data confirm that there is no cross-resistance with other antitubercular drugs. Under anaerobic conditions, PA-824 showed in vitro activity comparable to rifampin, moxifloxacin or gatifloxacin [87]. $\mathrm{Hu}$ et al. [90] reported that in a Hu/Coates model, PA-824 was much more active than moxifloxacin against both static and dormant bacilli.

3.2.2.2.4. In vivo efficacy in mice. In a mouse model of acute TB infection, PA-824 given orally at $25 \mathrm{mg} / \mathrm{kg}$ was as efficient as isoniazid $(25 \mathrm{mg} / \mathrm{kg}$ ) after 10 days of treatment [82]. In a mouse model of chronic infection, when administered as single daily dose, the minimal effective dose (MED) and the minimal bactericidal dose (MBD) of PA-824 were respectively $12.5 \mathrm{mg} / \mathrm{kg}$ and $100 \mathrm{mg} / \mathrm{kg}$

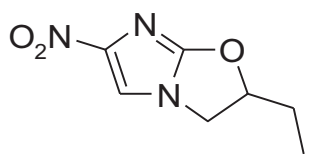

Fig. 6. Structure of CGI 17341
[88]. In the initial phase (2 months), PA-824 (100 mg/kg) was as active as isoniazid ( $25 \mathrm{mg} / \mathrm{kg}$ ) and no synergy between PA-824 and isoniazid was observed. However, this combination decreased dramatically the selection of INH-resistant mutants. More importantly, in the 4 months continuation phase (after a 2 month treatment with RIF/INH/PZA), PA-824 (100 mg/kg) exhibited an activity significantly better compared to isoniazid $(25 \mathrm{mg} / \mathrm{kg}$ ) or moxifloxacin $(100 \mathrm{mg} / \mathrm{kg})$ and equivalent to the combination RIF/INH [88]. Nuermberger et al. [91] used RIF/MXF/PZA as a reference regimen and showed that $\mathrm{PA}-824$ substituted well for rifampin in a 6 months treatment (2 months with RIF(or PA-824)/MXF/PZA and 4 months with RIF(or PA-824)/MXF). However, addition of PA-824 was unable to shorten the duration of treatment RIF/MXF/PZA from four months to three months. Finally, Tasnen et al. [92] showed that in a chronic infection model, the combination RIF/ PA-824 (100 mg/kg)/PZA was more active than the standard regimen RIF/INH/PZA in both initial and continuation phase. It was also observed that the activity of PA-824 alone was strikingly increased when pyrazinamide was added [92].

3.2.2.2.5. In vivo efficacy in guinea pigs. In a chronic infection model of TB in guinea pigs, similar results were obtained for the treatment of the infection with PA-824 $(40 \mathrm{mg} / \mathrm{kg})$ and isoniazid (25 mg/kg), after 28 days [82]. Sung et al. [93] reported a drypowder aerosol formulation of PA-824 which demonstrated a high stability (more than 6 months at room temperature and more than one year at $4{ }^{\circ} \mathrm{C}$ ). Pharmacokinetic parameters measured in guinea pigs were consistent with the previously obtained data. The inhalation route exhibited a better pharmacokinetic profile than oral or i.v. administration. However, in a guinea pig model, PA824 aerosols showed modest but still encouraging activity compared to oral administration because of the lower dose absorbed by inhalation. Moreover, PA-824 aerosol was more efficient to prevent formation of granuloma in white pulp compared to oral PA824 suspension [94].

3.2.2.2.6. Phase 1. In healthy volunteers, after single oral administrations ranging from 50 to $1500 \mathrm{mg}$, the $C_{\max }$ was reached after $4-5 \mathrm{~h}$ and ranged from 0.3 to $2.9 \mu \mathrm{g} / \mathrm{mL}$. AUC was also dosedependent and ranged from 7.5 to $101.8 \mu \mathrm{g} \mathrm{h} / \mathrm{mL}$ with a plateau reached with the dose of $1 \mathrm{~g}$. The mean half-life was around $18 \mathrm{~h}$. In the 7 days multiple-dose study, steady state was achieved after 5-6 days for 200 and $600 \mathrm{mg}$ dose groups. To understand a previously observed increase in serum creatinine during multiple-dose study [95], an experiment was performed on 47 healthy patients in order to evaluate effect of PA-824 on their renal function. PA-824 up to $1 \mathrm{~g} /$ day for 8 days was shown to be safe and well tolerated [96].

3.2.2.2.7. Phase 2. A randomized study [97] with 69 drugsensitive, smear-positive pulmonary TB patients showed that the use of four doses ( $200 \mathrm{mg}, 600 \mathrm{mg}, 1000 \mathrm{mg}, 1200 \mathrm{mg}$ ) led to the same EBA of $0.1 \log \mathrm{CFU} / \mathrm{day} / \mathrm{mL}$. These results suggested that the parameter which drives the EBA was the time above MIC rather than the ratios AUC/MIC or $C_{\max } / \mathrm{MIC}$. This hypothesis has been confirmed recently in a mouse model [89].

Two new EBA experiments with PA-824 alone or in combination with known antitubercular drugs are ongoing [98].

3.2.2.3. OPC-67683. OPC-67683 (Delamanid, Table 2) was designed from CGI 17341 (Fig. 6) with the objective to enhance its TB-activity and to lower its toxicity [99].

3.2.2.3.1. Chemical synthesis. The chemical synthesis of OPC67683 is based on a convergent strategy described in Fig. 8 [99]. The first synthon is obtained by a Buchwald palladium-catalyzed arylation of 4-(4-(trifluoromethoxy)phenoxy)piperidine. Then the removal of the tetrahydropyran protecting group affords the desired phenol. The second synthon is prepared from 2-chloro4-nitroimidazole which is mono-alkylated with an epoxide. 


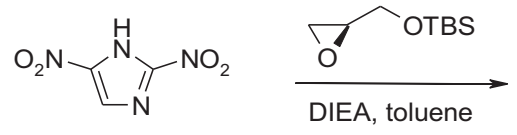<smiles>O=[N+]([O-])c1cn(CC(O)CO[SbH3])c([N+](=O)[O-])n1</smiles>

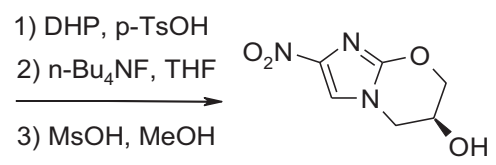

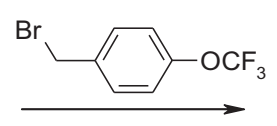

$\mathrm{NaH}, \mathrm{DMF}$<smiles>O=[N+]([O-])c1cn2c(n1)OC[C@@H](OCc1ccc(OC(F)(F)F)cc1)C2</smiles>

Fig. 7. Synthetic pathway for PA-824.

De-esterification of the product gives a diol which is converted to an epoxide after selective mesylation and cyclization. Coupling of the two synthons followed by intramolecular ring-closure leads to OPC-67683.

3.2.2.3.2. Target and mechanism of action. OPC-67683 is a structurally close analogue of PA-824 and it inhibits methoxy-mycolic and keto-mycolic acids biosynthesis with $\mathrm{IC}_{50}$ values respectively equal to $0.036 \mu \mathrm{g} / \mathrm{mL}$ and $0.021 \mu \mathrm{g} / \mathrm{mL}$. Moreover, as observed for PA-824, deazaflavin-dependent nitroreductase bioreduces OPC67683 into the corresponding des-nitro metabolite [100].

3.2.2.3.3. In vitro activity against $M$. tuberculosis. MIC ranging from 0.006 to $0.0134 \mu \mathrm{g} / \mathrm{mL}$ were measured against both drugsensitive and drug resistant strains (more than 70 strains) [100]. No antagonistic activity of OPC-67683 was observed when combined with rifampin, isoniazid, ethambutol and streptomycin. OPC-67683 was very potent on intracellular M. tuberculosis: at
$0.1 \mu \mathrm{g} / \mathrm{mL}$ it was as active as rifampin at $3 \mu \mathrm{g} / \mathrm{mL}$ and more active than isoniazid and PA-824 at 3 and $1 \mu \mathrm{g} / \mathrm{mL}$ respectively.

3.2.2.3.4. In vivo efficacy in mice. In a mouse model of chronic tuberculosis, a reduction of $95 \%$ in CFU count was obtained with OPC-67683 at a dose of $0.625 \mathrm{mg} / \mathrm{kg}$ whereas 3.5, 5, 40 and $160 \mathrm{mg} /$ $\mathrm{kg}$ of respectively rifampin, isoniazid, pyrazinamide and streptomycin were needed to achieve the same activity [100]. Similar activities were recorded in immunocompetent or immunocompromised BALB/c mice. The combination OPC-67683 $(2.5 \mathrm{mg} / \mathrm{kg}) /$ RIF ( $5 \mathrm{mg} / \mathrm{kg}$ )/PZA (100 mg/kg) was found to be much more active than the standard regimen RIF (5 mg/kg)/PZA (100 mg/kg)/INH (10 mg/kg)/EMB (100 mg/kg).

3.2.2.3.5. Pharmacokinetics. In $M$. tuberculosis infected mice model, OPC-67683 at a dose of $2.5 \mathrm{mg} / \mathrm{kg}$ reached after $6 \mathrm{~h}$ a $C_{\max }$ of $0.297 \mu \mathrm{g} / \mathrm{mL}$. An AUC of $4.13 \mu \mathrm{g} \mathrm{h} / \mathrm{mL}$ and a half-life of $7.6 \mathrm{~h}$ were measured [100]. OPC-67683 is not a substrate of human CYP
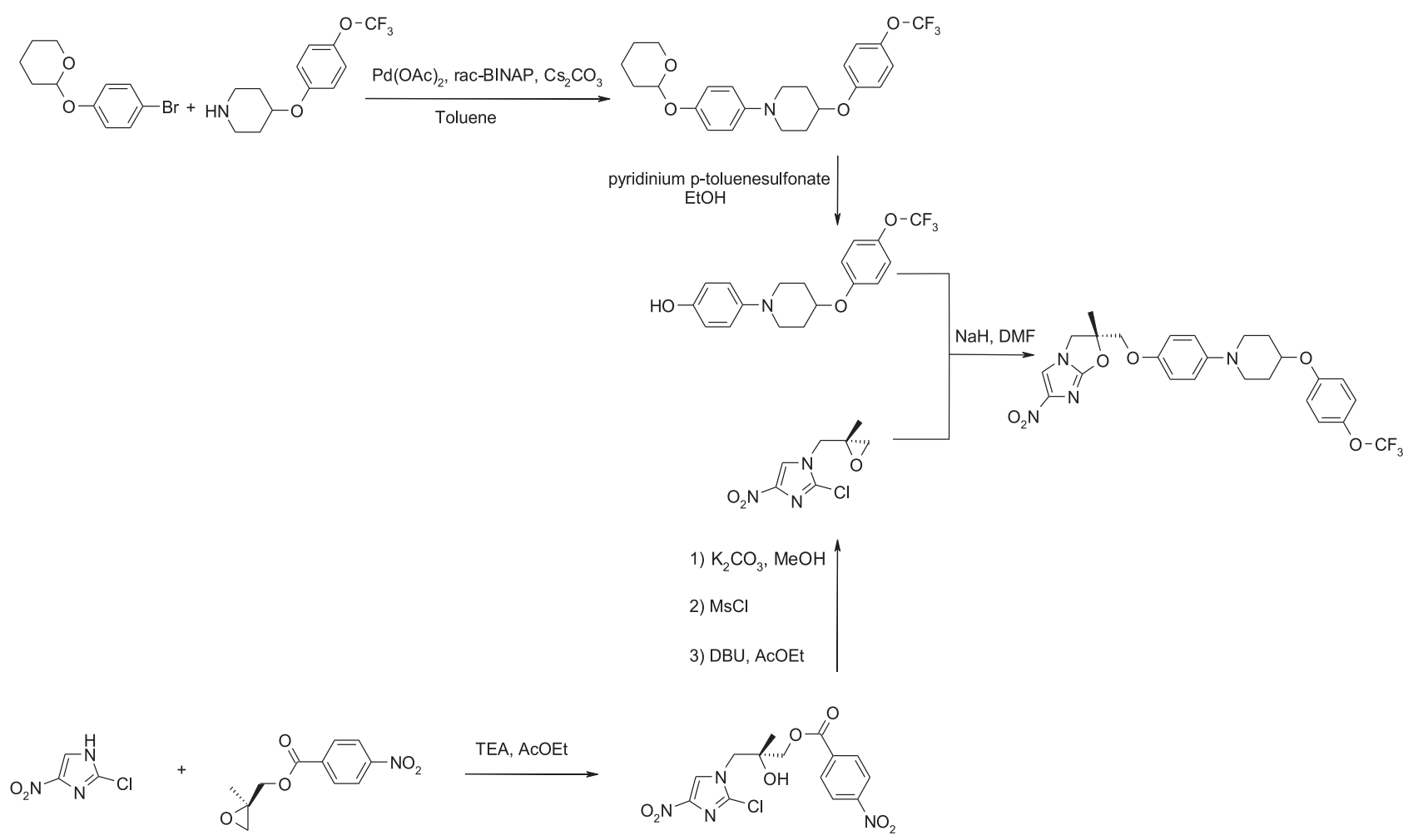

Fig. 8. Synthetic pathway for OPC-67683. 
enzymes, and it has neither inhibitory nor inductive effect on CYP at concentrations up to $100 \mu \mathrm{M}$ [100].

In smear-positive pulmonary TB patients [101], in a 14 days multiple-dose study, $C_{\max }$ and $\mathrm{AUC}_{0-24 \mathrm{~h}}$ overlapped across dosages and reached a plateau at $300 \mathrm{mg}$, certainly due to poor absorption. For all patients, $t_{\max }$ ranged from 4 to $5 \mathrm{~h}$. At all dosages OPC-67683 was well tolerated and did not exhibit any toxicity.

3.2.2.3.6. Phase 2. An EBA study was conducted in 48 patients with smear-positive TB, receiving $100,200,300$ or $400 \mathrm{mg}$ of OPC-67683 daily during 14 days [101]. Albeit no significant differences between the four dosages were observed (an average EBA of $0.040 \log$ CFU/mL/day was measured) the frequency of patients presenting a better response with $200 \mathrm{mg}$ and $300 \mathrm{mg}$ was noticed.

A second phase 2 study has already been completed and one is ongoing [102]. The aim of these studies is to evaluate the efficacy, safety and pharmacokinetics of OPC-67683 in patients with pulmonary MDR-TB.

\subsubsection{Diamine derivative: SQ109}

SQ109 (Table 2) is a synthetic analogue of ethambutol [103]. It was discovered from a focused library of ethylenediamine analogues containing 63,238 compounds [104].

3.2.3.1. Chemical synthesis. The solution phase organic synthesis of SQ109 is described in Fig. 9. Trans-trans farnesyl bromide is substituted by ethylenediamine to yield the corresponding monosubstituted amine. Reductive amination performed with 2-adamantanone yields the desired 2-adamantyldiamine SQ109 [105].

3.2.3.2. Target and mechanism of action. The exact mechanism of action of SQ109 is not yet known. SQ109, as ethambutol, was shown to over-produce the ATP-dependent DNA/RNA helicase and to reduce the production of the $\beta$-ketoacyl-acyl carrier protein synthase which may explain its action on mycobacterial cell wall synthesis [106]. Interestingly, SQ109 is still active against EMBresistant strains, therefore SQ109 is believed to act in a different manner than ethambutol [103]. It was also shown that SQ109 is active against RIF-resistant strains [107].

3.2.3.3. In vitro activity against M. tuberculosis. SQ109 MIC reported in the literature ranges from $0.63 \mu \mathrm{M}$ [104] to 1.56 [103] on drugsensitive strains, is equal to $0.9 \mu \mathrm{M}$ on EMB-resistant strain, $1.4 \mu \mathrm{M}$ on INH-resistant strain and $0.7 \mu \mathrm{M}$ on RIF-resistant strain [103]. Recently, SQ109 and TMC207 have been studied in combination on M. tuberculosis H37Rv culture. Activity of TMC207 was improved by 4 - to 8 -fold in the presence of SQ109. Moreover, the rate of killing bacteria was higher in combination than for drugs alone [108]. SQ109 also showed synergistic effect with antitubercular drugs isoniazid and rifampin [107].

3.2.3.4. In vivo efficacy in mice. SQ109 was shown more effective than ethambutol in vivo. In a chronic mouse model of TB, SQ109 at $10 \mathrm{mg} / \mathrm{kg}$ and $25 \mathrm{mg} / \mathrm{kg}$ was able to reduce the number of lung CFU and spleen CFU respectively by $1.5-2.5 \log$ after 30 days of treatment, activity that was similar to monotherapy with ethambutol at $100 \mathrm{mg} / \mathrm{kg}$ [103]. In vivo studies in the same model showed that substitution of SQ109 $(10 \mathrm{mg} / \mathrm{kg})$ for ethambutol $(100 \mathrm{mg} / \mathrm{kg})$ improved efficacy of first-line drug therapy combination after 4 or 8 weeks of treatment [109].

3.2.3.5. Pharmacokinetics. In mouse, oral administration of $10 \mathrm{mg} /$ $\mathrm{kg}$ for 28 days resulted in a plasma concentration equivalent to 10 times the MIC. However, oral bioavailability of SQ109 was low (8\%) and in general, SQ109 concentrations were higher in organs than in plasma. SQ109 plasma concentration-time course after single oral administration $\left(25 \mathrm{mg} / \mathrm{kg}\right.$ ) to mice was $0.254 \mu \mathrm{g} \mathrm{h} / \mathrm{mL}$, and $C_{\max }$ and $T_{\max }$ were respectively $0.135 \mu \mathrm{g} / \mathrm{mL}$ and $0.31 \mathrm{~h}$ [110]. SQ109 was shown to be oxidized and $\mathrm{N}$-dealkylated, predominantly involving the human CYP2D6 and CYP2C19 [111].

3.2.3.6. Phase 1. SQ109 has completed three phase 1 studies in the USA. A phase 1 double-blind, placebo-controlled study performed on 62 healthy adults showed that oral doses of SQ109 up to $300 \mathrm{mg}$ were safe and well tolerated. SQ109 was rapidly distributed to tissues and presented a long half-life of 61 h [112]. In 2007, the U.S. Food and Drug Administration (FDA) and the European Medicines Agency (EMEA) granted SQ109 orphan drug status for the treatment of TB. Another phase 1 has been completed in 2009. This study was performed to determine safety and pharmacokinetics of multiple-doses of SQ109 in healthy volunteers. Results are not yet published. SQ109 is currently being evaluated in a phase 2a trial in adults with smear-positive pulmonary TB [113].

\subsubsection{Oxazolidinones}

3.2.4.1. Linezolid. Linezolid (Table 2) was introduced in the USA for the treatment of patients with infections caused by Gram-positive pathogens (Staphylococci, Streptococci and Entercocci) responsible for skin and soft tissue infections, pneumonias and bacteraemias [114]. Linezolid is used for courses of treatment up to 28 days. This compound belongs to the (S)-oxazolidin-2-one family class of compounds and is a direct analogue of DuP105 and DuP721 (Fig. 10) described to have MIC of $0.3-1.25 \mu \mathrm{g} / \mathrm{mL}$ against $M$. tuberculosis [80] and which development was discontinued in Phase 1 due to toxicity issues.<smiles>CC(C)=CCC/C(C)=C/CBr</smiles>

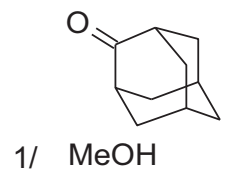

2/ $\mathrm{NaBH}_{4}$<smiles>CC(C)=CCC/C(C)=C/CNCCNC1C2CC3CC(C2)CC1C3</smiles>

Fig. 9. Synthetic pathway for SQ109. 
3.2.4.1.1. Chemical synthesis. The synthesis of linezolid at the process scale is described in Fig. 11 [115]. N-carbobenzoxy-3-fluoro4-morpholinylaniline is synthesized from commercially available 3,4-difluoro-nitrobenzene by nucleophilic aromatic displacement with morpholine, followed by reduction and functionalization of the resulting amine in benzyl carbamate. Nitrogen deprotonation is obtained with lithium $t$-amylate and substitution of $\mathrm{S}-(+)-3-$ chloro-1,2-propanediol is followed by cyclization into oxazolidinone. Primary alcohol is then reacted with 3-nitrobenzenesulfonyl chloride and treated with aqueous ammonium hydroxide to give the corresponding primary amine. Following acylation to yield linezolid is performed with acetic anhydride [116].

3.2.4.1.2. Target and mechanism of action. Linezolid presents a unique mechanism of action which was supported by the lack of cross-resistance between oxazolidinones and other antibiotics. It binds to the 23S RNA in the 50S ribosomal subunit and limits the growth of bacteria by disrupting its production of proteins in the first step of the synthesis by inhibiting formation of the initiation complex [117].

3.2.4.1.3. In vitro activity against $M$. tuberculosis. Linezolid has a high in vitro antibacterial activity (MIC of $0.125-0.5 \mu \mathrm{g} / \mathrm{mL}$ ) against $M$. tuberculosis [114,118-120].

3.2.4.1.4. In vivo efficacy in mice. In an acute mouse model of infection, linezolid given at $100 \mathrm{mg} / \mathrm{kg}$, one day after infection and 5 days a week for four weeks was able to reduce bacterial growth in spleen and lung, unfortunately in a less efficient manner than isoniazid $(25 \mathrm{mg} / \mathrm{kg})$ [121].

3.2.4.1.5. Clinical phases. Only few Phase 1 and 2 clinical data have been published so far. EBA and extended EBA of linezolid has been studied in patients with pulmonary TB [122]. Linezolid at $600 \mathrm{mg} /$ day presented weak early and extended bactericidal activities when given once or twice daily to patients with pulmonary TB [122]. Efficacy of linezolid to treat MDR-TB in combination regimens was assessed in two studies with a total of 11 patients $[123,124]$. Doses of 600 and $1200 \mathrm{mg} /$ day allowed sputum and cultures to become negatives and some patients were cured after treatment. However toxic side effects such as peripheral and optic neuropathy were common. Today linezolid is used off-label as a third-line agent in combination regimens to treat MDR-TB or XDR-TB [125].

3.2.4.2. PNU-100480. As discussed previously, the use of linezolid is limited by adverse effects that occur with long-term administrations. Therefore, new analogues showing identical or better in vivo activities and a better therapeutic index would be useful. The development of PNU-100480 (Sutezolid, Table 2), a close structural analogue of linezolid was initiated by Upjohn.

3.2.4.2.1. Chemical synthesis. With the exception of morpholine that was replaced by a thiomorpholine, the synthesis procedure of PNU-100480 is closely parallel to the one of linezolid (Fig. 11).

3.2.4.2.2. In vitro activity against $M$. tuberculosis. PNU-100480 exhibits a MIC range of $0.03-0.50 \mu \mathrm{g} / \mathrm{mL}$ against a panel of 5 sensitive and 5 drug resistant strains of $M$. tuberculosis, which makes it, in average, 3.2 times more efficient than linezolid $[118,126]$. Its sulfoxide and sulfone metabolites (PNU-101603 and PNU-101244) was shown to contribute to its activity.

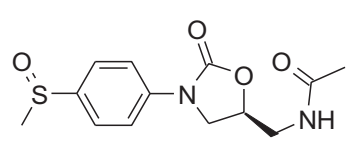

DuP105

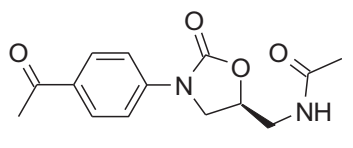

DuP721
Fig. 10. Structures of oxazolidinone derivatives DuP105 and DuP721.
3.2.4.2.3. In vivo efficacy in mice. PNU- 100480 is more potent than linezolid in the mouse model and its potency was comparable to isoniazid [121,127]. Moreover, PNU-100480 significantly improves the initial bactericidal activity of several combinations of existing first-line drugs [128].

3.2.4.2.4. Phase 1. Trials with PNU-100480 have been completed [129] and published [130,131]. These studies were designed to assess safety, tolerability, pharmacokinetics and for the first time mycobactericidal activities, measured in ex-vivo whole-blood culture, of single or multiple ascending doses of PNU-100480. In both studies, doses up to $1200 \mathrm{mg} /$ day were well tolerated; exposure increased linearly with dose and antimycobacterial activity was superior to linezolid. No haematologic safety signals in healthy volunteers were observed with optimal dose of PNU-100480: $600 \mathrm{mg}$ twice daily for 28 days. In the multiple-dose study, synergestic effect with PZA was observed. A phase 2a to assess EBA of PNU-100480 is ongoing [132].

\subsection{Compound in phase 1 clinical trials: oxazolidinone AZD5847}

Structure, mode of action and calculated physico-chemical properties [36] of AZD5847 in phase 1 clinical trials are reported in Table 3.

New oxazolidinone derivative, AZD5847 (also known as AZD2563) currently in phase 1 clinical trials (Table 3), is developed by AstraZeneca. Two studies, a single ascending dose and multiple ascending dose over 14 days, have now been completed for AZD5847 [133]. Bioavailability in fasted volunteers was reported to decrease with increasing doses, declining from $100 \%$ at $50 \mathrm{mg}$ to less than $30 \%$ at $1200 \mathrm{mg}$. However, this tendency was corrected by food intake. AZD5847 was tolerated over 14 days in healthy volunteers. The doses selected for investigation in phase 2 studies are $500 \mathrm{mg}$ once and twice daily, $800 \mathrm{mg}$ twice daily and $1200 \mathrm{mg}$ once daily and will be compared to Rifafour ${ }^{\circledR}$ (RIF/INH/PZA/EMB) 1 pill per os once daily [134]. A phase 2a is scheduled to start in 2012.

\subsection{Compounds in preclinical development}

Structure, mode of action and calculated physico-chemical properties [36] of compounds in preclinical development are reported in Table 4.

\subsubsection{Fluoroquinolone: DC-159a}

As moxifloxacin and gatifloxacin, DC-159a (Table 4) belongs to a new generation of fluoroquinolones.

3.4.1.1. Target and mechanism of action. The mechanism of action of DC-159a is still under investigation, but as other quinolone derivatives, DC-159a probably affects GyrA activity, which plays important roles in DNA replication $[135,136]$. However DC-159a-resistant mutants revealed patterns of mutations in GyrA different than the ones observed in quinolones-resistant strains [137]. DC-159a showed better in vitro and in vivo activities against quinolone resistant multidrug resistant tuberculosis strains (QR-MDR-TB) than some other fluoroquinolones [137]. Therefore, it has been proposed that DC-159a may be a replacement drug for the treatment of QR-MDR cases.

3.4.1.2. In vitro activity against $M$. tuberculosis. DC-159a showed $\mathrm{MIC}_{90}$ of $0.06 \mu \mathrm{g} / \mathrm{mL}$ against drug susceptible strains $(n=21)$ and $0.5 \mu \mathrm{g} / \mathrm{mL}$ against QR-MDR strains $(n=11)$ [138]. In that study, DC159a was 4-32 fold more active than the three classic quinolone drugs levofloxacin, gatifloxacin and moxifloxacin. 

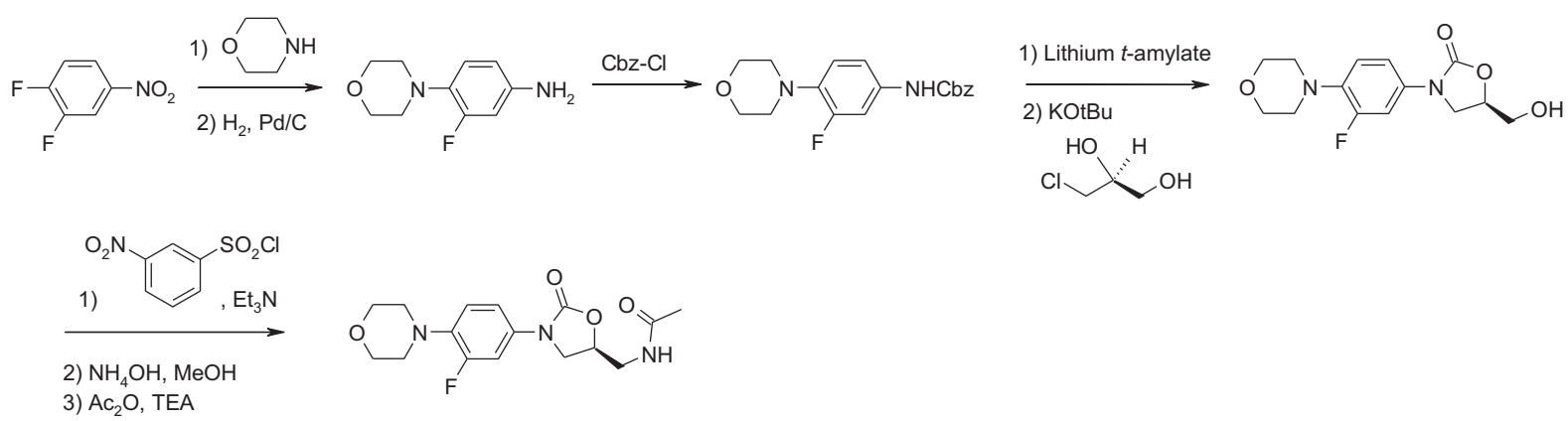

Fig. 11. Synthetic pathway for linezolid.

3.4.1.3. Pharmacokinetics. Single oral administrations ranging from 37.5 to $150 \mathrm{mg} / \mathrm{kg}$ showed a dose-dependent response in a murine TB model. At $100 \mathrm{mg} / \mathrm{kg}$ the DC-159a exposure in serum $\left(\mathrm{AUC}_{0-\infty}\right.$ : $14.7 \mu \mathrm{g} \mathrm{h} / \mathrm{mL} ; C_{\max }: 10.3 \mu \mathrm{g} / \mathrm{mL}$ ) was comparable to that observed for moxifloxacin $[139,140]$. Furthemore, the concentration of DC159a in lungs of mice were approximately 4 times greater than that of serum at all doses. The half-life was observed at $1.51 \mathrm{~h}$ in serum and $1.93 \mathrm{~h}$ in lungs after a $100 \mathrm{mg} / \mathrm{kg}$ administration [139]. In a monkey model, slightly better pharmacokinetic properties $\left(\right.$ AUC $_{0-24}: 16.9 \mu \mathrm{g} \mathrm{h} / \mathrm{mL} ; C_{\text {max }}: 2.20 \mu \mathrm{g} / \mathrm{mL}$ ) were found for DC-159a at $5 \mathrm{mg} / \mathrm{kg}$ compare to levofloxacine [138].

3.4.1.4. In vivo efficacy in mice. In $M$. tuberculosis $\mathrm{H} 37 \mathrm{Rv}$ infected mice, during the initial phase of treatment ( 2 months), the activity of DC-159a alone $(25 \mathrm{mg} / \mathrm{kg})$ was superior to moxifloxacin at $25 \mathrm{mg} / \mathrm{kg}$ and equivalent to moxifloxacin at $50 \mathrm{mg} / \mathrm{kg}$ [140]. During the 2 months continuation phase (after a 2 months treatment with $\mathrm{RIF} / \mathrm{INH} / \mathrm{PZA}$ ), DC-159a at $100 \mathrm{mg} / \mathrm{kg}$ displayed the same bactericidal activity as isoniazid (10 $\mathrm{mg} / \mathrm{kg}$ ) and a statistically superior activity to moxifloxacin at $100 \mathrm{mg} / \mathrm{kg}$ [140]. EBA of DC-159a was evaluated in mice with a drug susceptible $M$. tuberculosis infection model [139]. At $100 \mathrm{mg} / \mathrm{kg}$ DC-159a exhibited the best EBA at 3, 6 and 9 days of treatment, compared to moxifloxacin $(100 \mathrm{mg} / \mathrm{kg})$, levofloxacine $(100 \mathrm{mg} / \mathrm{kg})$, isoniazid $(10 \mathrm{mg} / \mathrm{kg}$ ) and rifampin (20 mg/kg). Unlike moxifloxacin, DC-159a enhanced its activity (log reduction of CFU in lungs) continuously from day 3-9. After 9 days of treatment, DC-159a (50 mg/kg), isoniazid (10 mg/kg) and rifampin $(20 \mathrm{mg} / \mathrm{kg})$ demonstrated an equivalent activity. The efficacy of DC-159a was evaluated in lungs of mice infected by QRMDR-TB after two weeks of treatment [139]. DC-159a at $100 \mathrm{mg} / \mathrm{kg}$

Table 3

Structure and calculated physico-chemical properties of AZD5847 in phase 1 clinical trials [36].

\begin{tabular}{ll}
\hline Name & AZD5847 \\
Family & Protein synthesis inhibitor \\
Mode of action & 465.4 \\
MW & 1.44 \\
clogP & 7 \\
H-bond acc. & 2 \\
H-bond don. & 125.6 \\
PSA & 7 \\
Nb rotules & \\
\hline
\end{tabular}

significantly inhibited $M$. tuberculosis growth in lungs (2 log CFU reduction). In the same study, treatment of QR-MDR-TB infected mice with 50,75 and $100 \mathrm{mg} / \mathrm{kg}$ of DC-159a, recorded notable superior mean survival compared to untreated control and to moxifloxacin (100 mg/kg), levofloxacin (100 mg/kg), rifampin $(20 \mathrm{mg} / \mathrm{kg})$ or isoniazid $(10 \mathrm{mg} / \mathrm{kg})$ treatments. Additional preclinical studies are currently in progress.

\subsubsection{Diamine derivative: SQ609}

While SQ109 was under development, several new dipiperidine analogues were designed and they demonstrated activity against M. tuberculosis [141]. The solid-phase synthesis and screening of a focused library of 10,358 diamines led to the discovery of dipiperidine analogue SQ609 (Table 4). In M. tuberculosis infected macrophages in vitro, a concentration of $4 \mu \mathrm{g} / \mathrm{mL}$ of SQ609 was able to inhibit $90 \%$ of bacterial growth without showing any toxic effect. In vivo efficacy of SQ609 was evaluated in M. tuberculosis H37Rv infected mice. $\mathrm{C} 3 \mathrm{H} / \mathrm{He}$ mice intravenously infected were treated once daily with SQ609 at $10 \mathrm{mg} / \mathrm{kg}$ for 2 weeks. SQ609 was shown to prevent weight loss of the animals and was able to prolong therapeutic effect 2 weeks after the end of the treatment [142]. SQ609 is currently being evaluated in preclinical studies.

\subsubsection{Nitrophenyl derivatives}

3.4.3.1. BTZ043. A new class of sulphur containing heterocyclic called benzothiazinones (BTZ) has been recently described as potent antimycobacterial agents [143]. The structure-activity relationships study showed that sulphur atom and one or two nitro groups on the aromatic structure were required to inhibit bacterial growth in vitro. Compound BTZ038 (Table 4), was the most active of the series (Fig. 12).

3.4.3.1.1. Chemical synthesis. The synthesis of BTZ038 is described in Fig. 12. A 25\% aqueous solution of ammonia is added to a solution of 2-chloro-3-nitro-5-trifluoromethylbenzoyl chloride in acetonitrile to give 2-chloro-3-nitro-5-(trifluoromethyl)benzamide. The benzamide intermediate is treated with 1,4-dioxa-8azaspiro[4.5]decane-8-carbodithioic acid sodium salt, obtained from 4-piperidone [144], to yield substituted intermediate, which is cyclized in aqueous ethanolic solution. BTZ038 is obtained as crystalline solid after recrystallization [145].

3.4.3.1.2. In vitro and in vivo efficacy. Compound BTZ038 contains one stereogenic center and both S (BTZ043) and R (BTZ044) enantiomers were tested separately and were shown to be equipotent with MIC against $M$. tuberculosis and M. smegmatis respectively equal to 1 and $4 \mathrm{ng} / \mathrm{mL}$. Similar activities on a panel of MDR and XDR strains [146] indicated that this new family was acting on a new target. Two independent genetic approaches were applied to find the target of BTZ043. A decaprenylphosphoryl-beta-D-ribose 2'-epimerase called DprE1 (Rv3790) was validated as the BTZ043 target. It catalyses the 
Table 4

Structures and calculated physico-chemical properties of compounds in preclinical development [36].

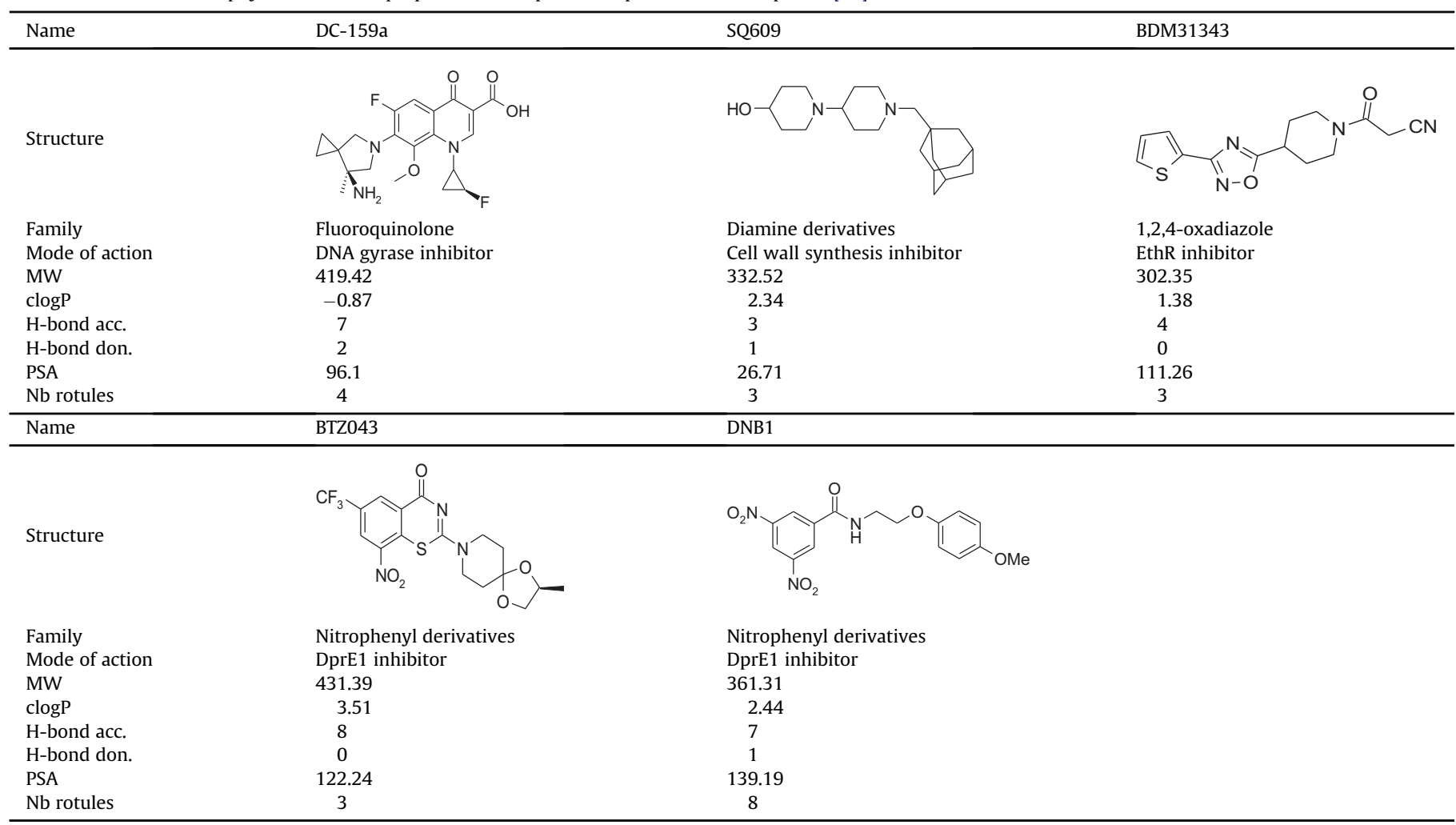

epimerization of decaprenylphosphoryl ribose to decaprenylphosphoryl arabinose, a precursor of arabinan synthesis, which is essential for cell wall synthesis [143]. Further metabolic studies indicated that BTZ043 is a prodrug and its mycobacterial reduction, leads to a nitroso derivative that covalently binds to Cys387 of DprE1 [143]. NfnB, a mycobacterial nitroreductase, was shown to contribute to the reduction of BTZ043 [147]. In vivo efficacy was assessed with BTZ043 in a mouse infection model. BALB/c mice were infected with a low bacillary load of $M$. tuberculosis H37Rv via aerosol then treated by gavage for 4 weeks with BTZ043 at 37.5 and $300 \mathrm{mg} / \mathrm{kg}$. Compound was suspended in carboxymethyl cellulose $(0.25 \%)$ and given once daily, six times a week. The $C_{\max }$ and AUC were measured and were found to be equal respectively to $2 \mu \mathrm{g} / \mathrm{mL}$ and $4.6 \mu \mathrm{g} \mathrm{h} / \mathrm{mL}$. Reduction of bacterial burden in lungs and spleen was respectively equal to 1 and 2 logs of CFU at the highest dose. BTZ043 is still evaluated in preclinical development.

3.4.3.2. DNB1. Dinitrobenzamide analogues as DNB1 (Table 4) were recently identified thanks to a phenotypic cell-based assay that uses automated confocal fluorescence microscopy $[148,149]$. They showed high activity against sensitive and XDR $M$. tuberculosis strains. These derivatives were also shown to inhibit decaprenylphospho-arabinose synthesis by targeting decaprenylphosphoribose $2^{\prime}$ epimerase DprE1 and are currently under development.

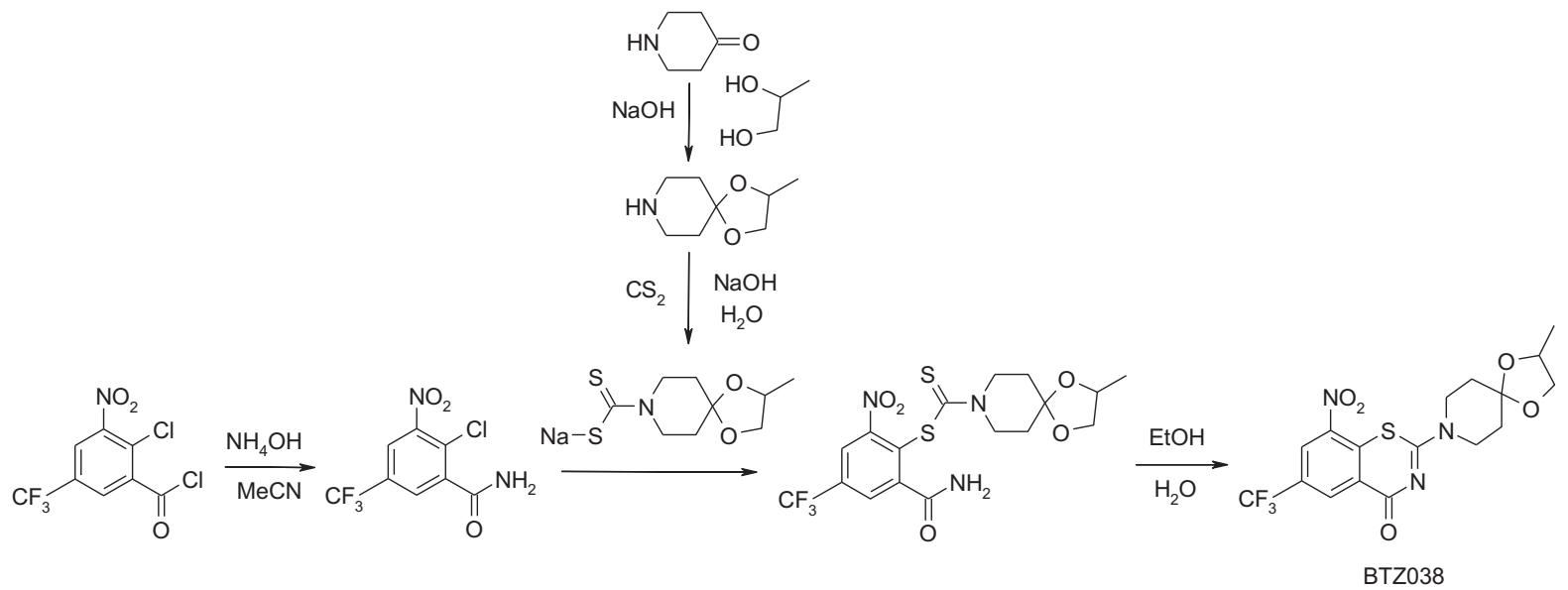

Fig. 12. Synthetic pathway for BTZ038. 

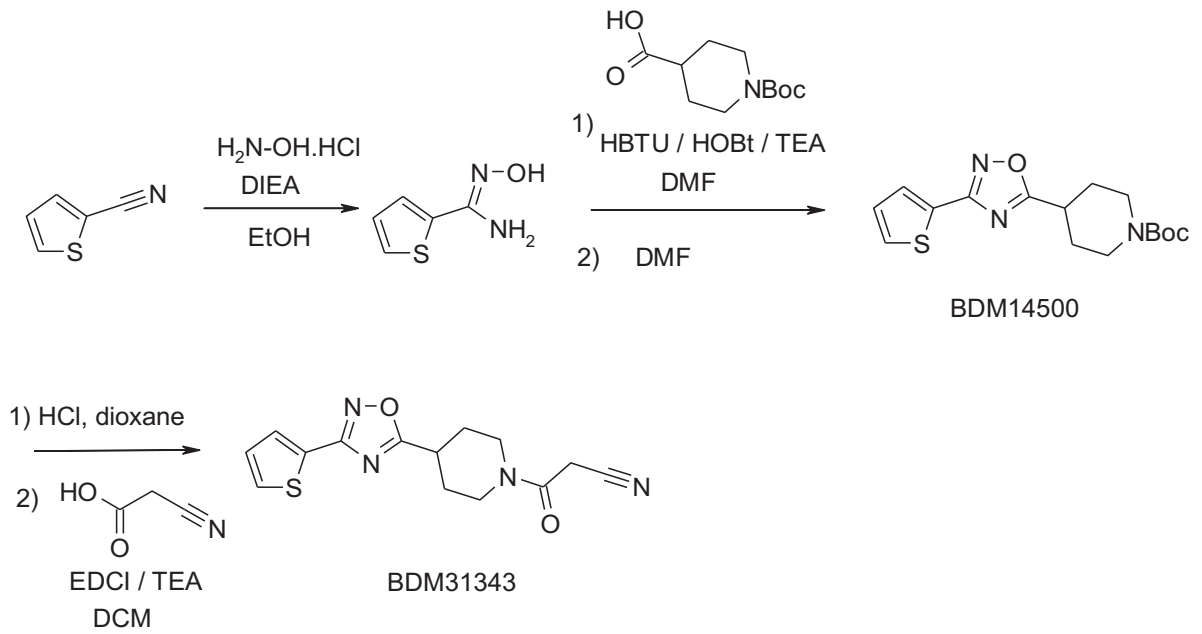

Fig. 13. Synthetic pathway for BDM31343.

\subsubsection{1,2,4-Oxadiazole derivative: BDM31343}

Many antituberculous agents are prodrugs. Among them, the second-line drug ethionamide is activated by a mycobacterial mono-oxygenase called EthA. The expression of eth $A$ and thus the potency of the drug are limited by the transcriptional repressor EthR [26]. In vitro overproduction of EthR was shown to confer resistance to ethionamide whereas EthA overproduction via eth $R$ KO conferred at least a 25 -fold increase of ethionamide potency [150]. A new concept emerged from this observation and drug-like inhibitors of EthR were designed and validated as boosters of ethionamide activity in order to improve therapeutic index of this antibiotic [151,152].

Hit compound BDM14500 (Fig. 13) was identified thanks to a functional screening of a focused library. BDM14500 was validated in vitro for its capacity to boost the antimycobacterial activity of ethionamide. BDM14500 was in the same time cocrystallized with EthR and revealed to occupy as expected the ligand binding domain of the protein. Optimization process led to the discovery of BDM31343 (Table 4) that proved to be 10 -fold more active, more soluble in aqueous solution and more stable in mouse liver microsomes [151].

3.4.4.1. Chemical synthesis. BDM31343 is synthesized in four steps from thiophene-2-carbonitrile. 1,2,4-oxadiazole ring synthesis is performed in DMF after acylation of 2-thiopheneamidoxime with Boc-isonipecotic acid. Finally, deprotection and acylation of piperidine with cyanoacetic acid yield the desired product (Fig. 13) [151].

3.4.4.2. In vivo efficacy in mice. At $100 \mathrm{mg} / \mathrm{kg}$, BDM31343 did not show any sign of toxicity and presented a mice exposure suitable for in vivo evaluation (AUC $=82 \mu \mathrm{g} \mathrm{h} / \mathrm{mL}$ ). The capacity of BDM31343 to reduce the mycobacterial load synergistically with ethionamide was evaluated in TB infected mice. Coadministration of ethionamide ( $3 \mathrm{mg} / \mathrm{kg}$ ) and BDM31343 (50 mg/kg, twice daily via intraperitoneal administration) during 3 weeks reduced the bacterial load all over the treatment as efficiently as a dose of $9 \mathrm{mg} /$ $\mathrm{kg}$ of ethionamide administered alone [151]. Thus BDM31343 was able to triple the activity of ethionamide in mice. Distribution study of BDM31343 in mouse using MALDI imaging revealed that the compound is localized in brain, lungs, liver and intestine [153]. Optimization of this 1,2,4-oxadiazole series led to the identification of more potent analogues showing a better pharmacokinetic profile $[154,155]$. Compounds are currently further evaluated in preclinical studies.

\section{Conclusion}

For the first time in 40 years, a large number of consortia and pharmaceutical companies have exhibited massive drug discovery efforts to develop new chemical series using either target-based or phenotypic screens. There are at least ten compounds in clinical trials and strategies for the development of new molecules are ready to fuel the pipeline. Most of them are still in preclinical testing but one might expect a candidate to rapidly reach the clinic. New targets have been identified and validated with drug-like molecules and the most advanced compound TMC207 might open a bright avenue for the TB treatment. Number of pharmaceutical companies involved in TB drug development projects has also increased. However, drug development is a long process especially for TB and it is likely that only one or two new drugs will arrive on the market from these efforts. Bacterial resistance and thus requirement for combinations of molecules tend to suggest that the current development pipeline is not yet sufficiently backed-up to overcome the major unmet medical needs in TB treatment. Efforts are still eagerly needed if we want to have soon a chance to win the battle against this millenary scourge.

\section{References}

[1] World Health Organization, Global Tuberculosis Control (2011), ISBN 97892 41564380.

[2] H.S. Cox, N. Ford, J.C. Reeder, Are we really that good at treating tuberculosis? Lancet Infect. Dis. 9 (2009) 138-139.

[3] G. Elzinga, M.C. Raviglione, D. Maher, Scale up: meeting targets in global tuberculosis control, Lancet 363 (2004) 814-819.

[4] C. Dye, B.G. Williams, The population dynamics and control of tuberculosis, Science 328 (2010) 856-861.

[5] Y. Zhang, The magic bullets and tuberculosis drug targets, Annu. Rev. Pharmacol. Toxicol. 45 (2005) 529-564.

[6] A. Schatz, S.A. Waksman, Effect of streptomycin and other antibiotic substances upon Mycobacterium tuberculosis and related organisms, Proc. Soc. Exp. Biol. Med. 57 (1944) 244-248.

[7] A.P. Carter, W.M. Clemons, D.E. Brodersen, R.J. Morgan-Warren, B.T. Wimberly, V. Ramakrishnan, Functional insights from the structure of the $30 \mathrm{~S}$ ribosomal subunit and its interactions with antibiotics, Nature 407 (2000) 340-348.

[8] R.T. Garvin, D.K. Biswas, L. Gorini, The effects of streptomycin or dihydrostreptomycin binding to 16S RNA or to 30S ribosomal subunits, Proc. Natl. Acad. Sci. U S A 71 (1974) 3814-3818.

[9] J. Bernstein, W.A. Lott, B.A. Steinberg, H.L. Yale, Chemotherapy of experimental tuberculosis. V. Isonicotinic acid hydrazide (nydrazid) and related compounds, Am. Rev. Tuberc. 65 (1952) 357-364.

[10] J. Rengarajan, C.M. Sassetti, V. Naroditskaya, A. Sloutsky, B.R. Bloom, E.J. Rubin, The folate pathway is a target for resistance to the drug para- 
aminosalicylic acid (PAS) in mycobacteria, Mol. Microbiol. 53 (2004) $275-282$.

[11] G.S. Timmins, V. Deretic, Mechanisms of action of isoniazid, Mol. Microbiol. 62 (2006) 1220-1227.

[12] F.G. Winder, P.B. Collins, Inhibition by isoniazid of synthesis of mycolic acids in Mycobacterium tuberculosis, J. Gen. Microbiol. 63 (1970) 41-48.

[13] L. Malone, A. Schurr, H. Lindh, D. McKenzie, J.S. Kiser, J.H. Williams, The effect of pyrazinamide (aldinamide) on experimental tuberculosis in mice, Am. Rev. Tuberc. 65 (1952) 511-518.

[14] Y. Zhang, D. Mitchison, The curious characteristics of pyrazinamide: a review, Int. J. Tubercul. Lung Dis. 7 (2003) 6-21.

[15] Y. Zhang, M.M. Wade, A. Scorpio, H. Zhang, Z. Sun, Mode of action of pyrazinamide: disruption of Mycobacterium tuberculosis membrane transport and energetics by pyrazinoic acid, J. Antimicrob. Chemother. 52 (2003) 790-795.

[16] W. Shi, X. Zhang, X. Jiang, H. Yuan, J.S. Lee, C.E. Barry, H. Wang, W. Zhang, Y. Zhang, Pyrazinamide inhibits trans-translation in Mycobacterium tuberculosis, Science 333 (2011) 1630-1632.

[17] J.P. Thomas, C.O. Baughn, R.G. Wilkinson, R.G. Shepherd, A new synthetic compound with antituberculous activity in mice: ethambutol (dextro2,2'-(ethylenediimino)-di-l-butanol), Am. Rev. Respir. Dis. 83 (1961) $891-893$.

[18] A.E. Belanger, G.S. Besra, M.E. Ford, K. Mikusova, J.T. Belisle, P.J. Brennan, J.M. Inamine, The embAB genes of Mycobacterium avium encode an arabinosyl transferase involved in cell wall arabinan biosynthesis that is the target for the antimycobacterial drug ethambutol, Proc. Natl. Acad. Sci. U S A 93 (1996) 11919-11924.

[19] G. Binda, E. Domenichini, A. Gottardi, B. Orlandi, E. Ortelli, B. Pacini, G. Fowst, Rifampicin, a general review, Arzneimittelforschung 21 (1971) 1907-1977.

[20] N. Maggi, C.R. Pasqualucci, R. Ballotta, P. Sensi, Rifampicin: a new orally active rifamycin, Chemotherapy 11 (1966) 285-292.

[21] W.R. McClure, C.L. Cech, On the mechanism of rifampicin inhibition of RNA synthesis, J. Biol. Chem. 253 (1978) 8949-8956.

[22] D. Libermann, M. Moyeux, N. Rist, F. Grumbach, Preparation of new pyridinic thioamides active in experimental tuberculosis, C. R. Hebd. Seances Acad. Sci. 242 (1956) 2409-2412.

[23] A. Banerjee, E. Dubnau, A. Quemard, V. Balasubramanian, K.S. Um, T. Wilson, D. Collins, G. de Lisle, W.R. Jacobs Jr., INHA, a gene encoding a target for isoniazid and ethionamide in Mycobacterium tuberculosis, Science 263 (1994) 227-230.

[24] Y. Zhang, B. Heym, B. Allen, D. Young, S. Cole, The catalase-peroxidase gene and isoniazid resistance of Mycobacterium tuberculosis, Nature 358 (1992) 591-593.

[25] A.E. DeBarber, K. Mdluli, M. Bosman, L.G. Bekker, C.E. Barry 3rd, Ethionamide activation and sensitivity in multidrug-resistant Mycobacterium tuberculosis, Proc. Natl. Acad. Sci. U S A 97 (2000) 9677-9682.

[26] A.R. Baulard, J.C. Betts, J. Engohang-Ndong, S. Quan, R.A. McAdam, P.J. Brennan, C. Locht, G.S. Besra, Activation of the pro-drug ethionamide is regulated in mycobacteria, J. Biol. Chem. 275 (2000) 28326-28331.

[27] H.L. David, K. Takayama, D.S. Goldman, Susceptibility of mycobacterial Dalanyl-D-alanine synthetase to D-cycloserine, Am. Rev. Respir. Dis. 100 (1969) 579-581.

[28] N.E. Caceres, N.B. Harris, J.F. Wellehan, Z. Feng, V. Kapur, R.G. Barletta, Overexpression of the D-alanine racemase gene confers resistance to Dcycloserine in Mycobacterium smegmatis, J. Bacteriol. 179 (1997) 5046-5055.

[29] Z. Feng, R.G. Barletta, Roles of Mycobacterium smegmatis D-Alanine:D-Alanine ligase and D-Alanine racemase in the mechanisms of action of and resistance to the peptidoglycan inhibitor D-Cycloserine, Antimicrob. Agents Chemother. 47 (2003) 283-291.

[30] G.F. Busscher, F.P.J.T. Rutjes, F.L. van Delft, 2-Deoxystreptamine: central scaffold of aminoglycoside antibiotics ${ }^{\dagger}$, Chem. Rev. 105 (2005) 775-792

[31] W.H. Deitz, J.H. Bailey, E.J. Froelich, In vitro antibacterial properties of nalidixic acid, a new drug active against gram-negative organisms, Antimicrob. Agents Chemother. 161 (1963) 583-587.

[32] A.M. Emmerson, A.M. Jones, The quinolones: decades of development and use, J. Antimicrob. Chemother. 51 (2003) 13-20.

[33] C. Levine, H. Hiasa, K.J. Marians, DNA gyrase and topoisomerase IV: biochemical activities, physiological roles during chromosome replication, and drug sensitivities, Biochim. Biophys. Acta 1400 (1998) 29-43.

[34] L.A. Mitscher, Bacterial topoisomerase inhibitors: quinolone and pyridone antibacterial agents, Chem. Rev. 105 (2005) 559-592.

[35] A. Aubry, X.-S. Pan, L.M. Fisher, V. Jarlier, E. Cambau, Mycobacterium tuberculosis DNA gyrase: interaction with quinolones and correlation with antimycobacterial drug activity, Antimicrob. Agents Chemother. 48 (2004) 1281-1288.

[36] All the properties were calculated using PipelinePilot from Accelrys.

[37] B. Gaudillière, P. Berna, Ann. Rep. Med. Chem. 35 (2000) 340-343.

[38] J.P. Sanchez, R.D. Gogliotti, J.M. Domagala, S.J. Gracheck, M.D. Huband, J.A. Sesnie, M.A. Cohen, M.A. Shapiro, The synthesis, structure-activity, and structure-side effect relationships of a series of 8-alkoxy- and 5-amino-8alkoxyquinolone antibacterial agents, J. Med. Chem. 38 (1995) 4478-4487.

[39] U. Petersen, W. Schröck, D. Habich, A. Krebs, T. Schenke, T. Philipps, K. Grohe, R. Endermann, K.-D. Bremm, K.-G. Metzger, Quinolonecarboxylic acids, US 5480879 A (1996).
[40] J.C. Rodríguez, M. Ruiz, A. Climent, G. Royo, In vitro activity of four fluoroquinolones against Mycobacterium tuberculosis, Int. J. Antimicrob. Agents 17 (2001) 229-231.

[41] A. Aubry, N. Veziris, E. Cambau, C. Truffot-Pernot, V. Jarlier, L.M. Fisher, Novel gyrase mutations in quinolone-resistant and - hypersusceptible clinical isolates of Mycobacterium tuberculosis: functional analysis of mutant enzymes, Antimicrob. Agents Chemother. 50 (2006) 104-112.

[42] Y. Hu, A.R.M. Coates, D.A. Mitchison, Sterilizing activities of fluoroquinolones against rifampin-tolerant populations of Mycobacterium tuberculosis, Antimicrob. Agents Chemother. 47 (2003) 653-657.

[43] E.J. Alvirez-Freites, J.L. Carter, M.H. Cynamon, In vitro and in vivo activities of gatifloxacin against Mycobacterium tuberculosis, Antimicrob. Agents Chemother. 46 (2002) 1022-1025.

[44] E.L. Nuermberger, T. Yoshimatsu, S. Tyagi, K. Williams, I. Rosenthal, R.J. O’Brien, A.A. Vernon, R.E. Chaisson, W.R. Bishai, J.H. Grosset, Moxifloxacin-containing regimens of reduced duration produce a stable cure in murine tuberculosis, Am. J. Respir. Crit. Care Med. 170 (2004) 1131-1134.

[45] M. Ibrahim, C. Truffot-Pernot, K. Andries, V. Jarlier, N. Veziris, Sterilizing activity of R207910 (TMC207)-containing regimens in the murine model of tuberculosis, Am. J. Respir. Crit. Care Med. 180 (2009) 553-557.

[46] E.L. Nuermberger, T. Yoshimatsu, S. Tyagi, R.J. O’Brien, A.N. Vernon, R.E. Chaisson, W.R. Bishai, J.H. Grosset, Moxifloxacin-containing regimen greatly reduces time to culture conversion in murine tuberculosis, Am. J. Respir. Crit. Care Med. 169 (2004) 421-426.

[47] Moxifloxacin, Tuberculosis, 88 (2008) 127-131

[48] Gatifloxacin, Tuberculosis, 88 (2008) 109-111.

[49] A. Lubasch, I. Keller, K. Borner, P. Koeppe, H. Lode, Comparative pharmacokinetics of ciprofloxacin, gatifloxacin, grepafloxacin, levofloxacin, trovafloxacin, and moxifloxacin after single oral administration in healthy volunteers, Antimicrob. Agents Chemother. 44 (2000) 2600-2603.

[50] J.L. Johnson, D.J. Hadad, W.H. Boom, C.L. Daley, C.A. Peloquin, K.D. Eisenach, D.D. Jankus, S.M. Debanne, E.D. Charlebois, E. Maciel, M. Palaci, R. Dietze, Early and extended early bactericidal activity of levofloxacin, gatifloxacin and moxifloxacin in pulmonary tuberculosis, Int. J. Tubercul. Lung Dis. 10 (2006) 605-612.

[51] M.W.R. Pletz, A. De Roux, A. Roth, K.-H. Neumann, H. Mauch, H. Lode, Early bactericidal activity of moxifloxacin in treatment of pulmonary tuberculosis: a prospective, randomized study, Antimicrob. Agents Chemother. 48 (2004) $780-782$.

[52] J.-Y. Wang, J.-T. Wang, T.-H. Tsai, C.-L. Hsu, C.-J. Yu, P.-R. Hsueh, L.-N. Lee, P.C. Yang, Adding moxifloxacin is associated with a shorter time to culture conversion in pulmonary tuberculosis, Int. J. Tubercul. Lung Dis. 14 (2010) 65-71.

[53] S.E. Dorman, J.L. Johnson, S. Goldberg, G. Muzanye, N. Padayatchi, L. Bozeman, C.M. Heilig, J. Bernardo, S. Choudhri, J.H. Grosset, E. Guy, P. Guyadeen, M.C. Leus, G. Maltas, D. Menzies, E.L. Nuermberger, M. Villarino, A. Vernon, R.E. Chaisson, The tuberculosis trials, substitution of moxifloxacin for isoniazid during intensive phase treatment of pulmonary tuberculosis, Am. J. Respir. Crit. Care Med. 180 (2009) 273-280.

[54] M.B. Conde, A. Efron, C. Loredo, G.R.M. De Souza, N.P. Graça, M.C. Cezar, M. Ram, M.A. Chaudhary, W.R. Bishai, A.L. Kritski, R.E. Chaisson, Moxifloxacin versus ethambutol in the initial treatment of tuberculosis: a double-blind, randomised, controlled phase II trial, Lancet 373 (2009) 1183-1189.

[55] R. Rustomjee, C. Lienhardt, T. Kanyok, G.R. Davies, J. Levin, T. Mthiyane, C. Reddy, A.W. Sturm, F.A. Sirgel, J. Allen, D.J. Coleman, B. Fourie, D.A. Mitchison, A Phase II study of the sterilising activities of ofloxacin, gatifloxacin and moxifloxacin in pulmonary tuberculosis, Int. J. Tubercul. Lung Dis. 12 (2008) 128-138.

[56] L.R. Codecasa, G. Ferrara, M. Ferrarese, M.A. Morandi, V. Penati, C. Lacchini, P. Vaccarino, G.B. Migliori, Long-term moxifloxacin in complicated tuberculosis patients with adverse reactions or resistance to first line drugs, Respir. Med. 100 (2006) 1566-1572.

[57] Gatifloxacin clinicaltrials.gov (NCT ID: NCT00216385).

[58] Moxifloxacin clinicaltrials.gov (NCT ID: NCT00864383).

[59] J. Guillemont, Quinoline derivatives and their use as mycobacterial inhibitors, WO/2004/011436 (2004).

[60] N. Lounis, J. Guillemont, N. Veziris, A. Koul, V. Jarlier, K. Andries, R207910 (TMC207): a new antibiotic for the treatment of tuberculosis, Med. Mal. Infect. 40 (2010) 383-390.

[61] A.C. Haagsma, I. Podasca, A. Koul, K. Andries, J. Guillemont, H. Lill, D. Bald, Probing the interaction of the diarylquinoline TMC207 with its target mycobacterial ATP synthase, PLoS ONE 6 (2011) e23575.

[62] K. Andries, P. Verhasselt, J. Guillemont, H.W.H. Göhlmann, J.-M. Neefs, H. Winkler, J. Van Gestel, P. Timmerman, M. Zhu, E. Lee, P. Williams, D. de Chaffoy, E. Huitric, S. Hoffner, E. Cambau, C. Truffot-Pernot, N. Lounis, V. Jarlier, A diarylquinoline drug active on the ATP synthase of Mycobacterium tuberculosis, Science 307 (2005) 223-227.

[63] A. Koul, N. Dendouga, K. Vergauwen, B. Molenberghs, L. Vranckx, R. Willebrords, Z. Ristic, H. Lill, I. Dorange, J. Guillemont, D. Bald, K. Andries, Diarylquinolines target subunit c of mycobacterial ATP synthase, Nat. Chem. Biol. 3 (2007) 323-324.

[64] A.C. Haagsma, R. Abdillahi-Ibrahim, M.J. Wagner, K. Krab, K. Vergauwen, J. Guillemont, K. Andries, H. Lill, A. Koul, D. Bald, Selectivity of TMC207 towards mycobacterial ATP synthase compared with that towards the 
eukaryotic homologue, Antimicrob. Agents Chemother. 53 (2009) $1290-1292$.

[65] A. Koul, L. Vranckx, N. Dendouga, W. Balemans, I. Van den Wyngaert, K. Vergauwen, H.W.H. Göhlmann, R. Willebrords, A. Poncelet, J. Guillemont, D. Bald, K. Andries, Diarylquinolines are bactericidal for dormant mycobacteria as a result of disturbed ATP homeostasis, J. Biol. Chem. 283 (2008) 25273-25280.

[66] N. Lounis, N. Veziris, A. Chauffour, C. Truffot-Pernot, K. Andries, V. Jarlier Combinations of R207910 with drugs used to treat multidrug-resistan tuberculosis have the potential to shorten treatment duration, Antimicrob. Agents Chemother. 50 (2006) 3543-3547.

[67] N. Veziris, C. Truffot-Pernot, A. Aubry, V. Jarlier, N. Lounis, Fluoroquinolonecontaining third-line regimen against Mycobacterium tuberculosis in vivo, Antimicrob. Agents Chemother. 47 (2003) 3117-3122.

[68] N. Veziris, M. Ibrahim, N. Lounis, K. Andries, V. Jarlier, Sterilizing activity of second-line regimens containing TMC207 in a murine model of tuberculosis, PLoS ONE 6 (2011) e17556.

[69] N. Lounis, T. Gevers, J. Van Den Berg, K. Andries, Impact of the interaction of R207910 with rifampin on the treatment of tuberculosis studied in the mouse model, Antimicrob. Agents Chemother. 52 (2008) 3568-3572.

[70] R. Rustomjee, A.H. Diacon, J. Allen, A. Venter, C. Reddy, R.F. Patientia, T.C. Mthiyane, T. De Marez, R. van Heeswijk, R. Kerstens, A. Koul, K. De Beule, P.R. Donald, D.F. McNeeley, Early bactericidal activity and pharmacokinetics of the diarylquinoline TMC207 in treatment of pulmonary tuberculosis, Antimicrob. Agents Chemother. 52 (2008) 2831-2835.

[71] A.H. Diacon, A. Pym, M. Grobusch, R. Patientia, R. Rustomjee, L. Page-Shipp, C. Pistorius, R. Krause, M. Bogoshi, G. Churchyard, A. Venter, J. Allen, J.C. Palomino, T. De Marez, R.P.G. van Heeswijk, N. Lounis, P. Meyvisch, J. Verbeeck, W. Parys, K. de Beule, K. Andries, D.F.M. Neeley, The diarylquinoline TMC207 for multidrug-resistant tuberculosis, N. Engl. J. Med. 360 (2009) 2397-2405.

[72] T. De Marez, TMC207, WGND Annual Meeting, Lille, France, 2011.

[73] TMC207 clinicaltrials.gov (NCT ID: NCT01464762).

[74] L.G. Wayne, H.A. Sramek, Metronidazole is bactericidal to dormant cells of Mycobacterium tuberculosis, Antimicrob. Agents Chemother. 38 (1994) 2054-2058.

[75] D.I. Edwards, Mechanism of antimicrobial action of metronidazole, J. Antimicrob. Chemother. 5 (1979) 499-502.

[76] J.V. Brooks, S.K. Furney, I.M. Orme, Metronidazole therapy in mice infected with tuberculosis, Antimicrob. Agents Chemother. 43 (1999) 1285-1288.

[77] Metronidazole clinicaltrials.gov (NCT ID: NCT00425113).

[78] K.C. Agrawal, K.B. Bears, R.K. Sehgal, J.N. Brown, P.E. Rist, W.D. Rupp Potential radiosensitizing agents. Dinitroimidazoles, J. Med. Chem. 22 (1979) $583-586$.

[79] K. Nagarajan, R.G. Shankar, S. Rajappa, S.J. Shenoy, R. Costa-Pereira, Nitroimidazoles XXI 2,3-dihydro-6-nitroimidazo $[2,1-b]$ oxazoles with antitubercular activity, Eur. J. Med. Chem. 24 (1989) 631-633.

[80] D.R. Ashtekar, R. Costa-Perira, K. Nagrajan, N. Vishvanathan, A.D. Bhatt, W. Rittel, In vitro and in vivo activities of the nitroimidazole CGI 17341 against Mycobacterium tuberculosis, Antimicrob. Agents Chemother. 37 (1993) $183-186$

[81] W.R. Baker, C. Shaopei, E.L. Keeler, Nitroimidazole antibacterial compounds and methods of use thereof, WO/1997/001562 (1997).

[82] C.K. Stover, P. Warrener, D.R. VanDevanter, D.R. Sherman, T.M. Arain M.H. Langhorne, S.W. Anderson, J.A. Towell, Y. Yuan, D.N. McMurray, B.N. Kreiswirth, C.E. Barry, W.R. Baker, A small-molecule nitroimidazopyran drug candidate for the treatment of tuberculosis, Nature 405 (2000) 962-966.

[83] U.H. Manjunatha, H. Boshoff, C.S. Dowd, L. Zhang, T.J. Albert, J.E. Norton, L. Daniels, T. Dick, S.S. Pang, C.E. Barry, Identification of a nitroimidazooxazine-specific protein involved in PA-824 resistance in Mycobacterium tuberculosis, Proc. Natl. Acad. Sci. U S A 103 (2006) 431-436.

[84] U.H. Manjunatha, R. Lahiri, B. Randhawa, C.S. Dowd, J.L. Krahenbuhl, C.E. Barry, Mycobacterium leprae is naturally resistant to PA-824, Antimicrob. Agents Chemother. 50 (2006) 3350-3354.

[85] R. Singh, U. Manjunatha, H.I.M. Boshoff, Y.H. Ha, P. Niyomrattanakit, R. Ledwidge, C.S. Dowd, I.Y. Lee, P. Kim, L. Zhang, S. Kang, T.H. Keller, J. Jiricek, C.E. Barry, PA-824 kills nonreplicating Mycobacterium tuberculosis by intracellular NO release, Science 322 (2008) 1392-1395.

[86] U. Manjunatha, H.I. Boshoff, C.E. Barry, The mechanism of action of PA-824: novel insights from transcriptional profiling, Commun. Integr. Biol. 2 (2009) $215-218$

[87] A.J. Lenaerts, V. Gruppo, K.S. Marietta, C.M. Johnson, D.K. Driscoll, N.M. Tompkins, J.D. Rose, R.C. Reynolds, I.M. Orme, Preclinical testing of the nitroimidazopyran PA-824 for activity against Mycobacterium tuberculosis in a series of in vitro and in vivo models, Antimicrob. Agents Chemother. 49 (2005) 2294-2301.

[88] S. Tyagi, E. Nuermberger, T. Yoshimatsu, K. Williams, I. Rosenthal, N. Lounis, W. Bishai, J. Grosset, Bactericidal activity of the nitroimidazopyran PA-824 in a murine model of tuberculosis, Antimicrob. Agents Chemother. 49 (2005) 2289-2293.

[89] Z. Ahmad, C.A. Peloquin, R.P. Singh, H. Derendorf, S. Tyagi, A. Ginsberg, J.H. Grosset, E.L. Nuermberger, PA-824 exhibits time-dependent activity in a murine model of tuberculosis, Antimicrob. Agents Chemother. 55 (2011) $239-245$.
[90] Y. Hu, A.R.M. Coates, D.A. Mitchison, Comparison of the sterilising activities of the nitroimidazopyran PA-824 and moxifloxacin against persisting Mycobacterium tuberculosis, Int. J. Tubercul. Lung Dis. 12 (2008) 69-73.

[91] E. Nuermberger, S. Tyagi, R. Tasneen, K.N. Williams, D. Almeida, I. Rosenthal, J.H. Grosset, Powerful bactericidal and sterilizing activity of a regimen containing PA-824, moxifloxacin, and pyrazinamide in a murine model of tuberculosis, Antimicrob. Agents Chemother. 52 (2008) 1522-1524.

[92] R. Tasneen, S. Tyagi, K. Williams, J. Grosset, E. Nuermberger, Enhanced bactericidal activity of rifampin and/or pyrazinamide when combined with PA-824 in a murine model of tuberculosis, Antimicrob. Agents Chemother. 52 (2008) 3664-3668.

[93] J.C. Sung, L. Garcia-Contreras, J.L. VerBerkmoes, C.A. Peloquin, K.J. Elbert, A.J. Hickey, D.A. Edwards, Dry powder nitroimidazopyran antibiotic PA-824 aerosol for inhalation, Antimicrob. Agents Chemother. 53 (2009) $1338-1343$.

[94] L. Garcia-Contreras, J.C. Sung, P. Muttil, D. Padilla, M. Telko, J.L. VerBerkmoes, K.J. Elbert, A.J. Hickey, D.A. Edwards, Dry powder PA-824 aerosols for treatment of tuberculosis in guinea pigs, Antimicrob. Agents Chemother. 54 (2010) $1436-1442$

[95] A.M. Ginsberg, M.W. Laurenzi, D.J. Rouse, K.D. Whitney, M.K. Spigelman, Safety, tolerability, and pharmacokinetics of PA-824 in healthy subjects, Antimicrob. Agents Chemother. 53 (2009) 3720-3725.

[96] A.M. Ginsberg, M.W. Laurenzi, D.J. Rouse, K.D. Whitney, M.K. Spigelman, Assessment of the effects of the nitroimidazo-oxazine PA-824 on renal function in healthy subjects, Antimicrob. Agents Chemother. 53 (2009) 3726-3733.

[97] A.H. Diacon, R. Dawson, M. Hanekom, K. Narunsky, S.J. Maritz, A. Venter, P.R. Donald, C. van Niekerk, K. Whitney, D.J. Rouse, M.W. Laurenzi, A.M. Ginsberg, M.K. Spigelman, Early bactericidal activity and pharmacokinetics of PA-824 in smear-positive tuberculosis patients, Antimicrob. Agents Chemother. 54 (2010) 3402-3407.

[98] PA-824 clinicaltrials.gov (NCT ID: NCT01215851 and NCT00944021).

[99] H. Sasaki, Y. Haraguchi, M. Itotani, H. Kuroda, H. Hashizume, T. Tomishige, M. Kawasaki, M. Matsumoto, M. Komatsu, H. Tsubouchi, Synthesis and antituberculosis activity of a novel series of optically active 6-nitro-2,3dihydroimidazo[2,1-b]oxazoles, J. Med. Chem. 49 (2006) 7854-7860.

[100] M. Matsumoto, H. Hashizume, T. Tomishige, M. Kawasaki, H. Tsubouchi, H. Sasaki, Y. Shimokawa, M. Komatsu, OPC-67683, a nitro-dihydroimidazooxazole derivative with promising action against tuberculosis in vitro and in mice, PLoS Med. 3 (2006) e466.

[101] A.H. Diacon, R. Dawson, M. Hanekom, K. Narunsky, A. Venter, N. Hittel, L.J. Geiter, C.D. Wells, A.J. Paccaly, P.R. Donald, Early bactericidal activity of delamanid (OPC-67683) in smear-positive pulmonary tuberculosis patients, Int. J. Tubercul. Lung Dis. 15 (2011) 949-954.

[102] OPC-67683 clinicaltrials.gov (NCT ID: NCT01131351 and NCT00685360).

[103] M. Protopopova, C. Hanrahan, B. Nikonenko, R. Samala, P. Chen, J. Gearhart, L. Einck, C.A. Nacy, Identification of a new antitubercular drug candidate, SQ109, from a combinatorial library of 1,2-ethylenediamines, J. Antimicrob. Chemother. 56 (2005) 968-974.

[104] R.E. Lee, M. Protopopova, E. Crooks, R.A. Slayden, M. Terrot, C.E. Barry, Combinatorial lead optimization of [1,2]-Diamines based on ethambutol as potential antituberculosis preclinical candidates, J. Comb. Chem. 5 (2003) $172-187$

[105] O.K. Onajole, P. Govender, P.D.v. Helden, H.G. Kruger, G.E.M. Maguire, I. Wiid, T. Govender, Synthesis and evaluation of SQ109 analogues as potential antituberculosis candidates, Eur. J. Med. Chem. 45 (2010) 2075-2079.

[106] L. Jia, L. Coward, G.S. Gorman, P.E. Noker, J.E. Tomaszewski, Pharmacoproteomic effects of isoniazid, ethambutol, and $\mathrm{N}$-geranyl- $\mathrm{N}^{\prime}$-(2-adamantyl) ethane-1,2-diamine (SQ109) on Mycobacterium tuberculosis H37Rv, J. Pharmacol. Exp. Ther. 315 (2005) 905-911.

[107] P. Chen, J. Gearhart, M. Protopopova, L. Einck, C.A. Nacy, Synergistic interactions of SQ109, a new ethylene diamine, with front-line antitubercular drugs in vitro, J. Antimicrob. Chemother. 58 (2006) 332-337.

[108] V.M. Reddy, L. Einck, K. Andries, C.A. Nacy, In vitro interactions between new antitubercular drug candidates SQ109 and TMC207, Antimicrob. Agents Chemother. 54 (2010) 2840-2846.

[109] B.V. Nikonenko, M. Protopopova, R. Samala, L. Einck, C.A. Nacy, Drug therapy of experimental tuberculosis (TB): improved outcome by combining SQ109, a new diamine antibiotic, with existing TB drugs, Antimicrob. Agents Chemother. 51 (2007) 1563-1565.

[110] L. Jia, J.E. Tomaszewski, C. Hanrahan, L. Coward, P. Noker, G. Gorman, B. Nikonenko, M. Protopopova, Pharmacodynamics and pharmacokinetics of SQ109, a new diamine-based antitubercular drug, Br. J. Pharmacol. 144 (2005) 80-87.

[111] L. Jia, P.E. Noker, L. Coward, G.S. Gorman, M. Protopopova, J.E. Tomaszewski, Interspecies pharmacokinetics and in vitro metabolism of SQ109, Br. J. Pharmacol. 147 (2006) 476-485.

[112] Sequella press release.

[113] SQ109 clinicaltrials.gov (NCT ID: NCT01218217)

[114] S.J. Brickner, D.K. Hutchinson, M.R. Barbachyn, P.R. Manninen, D.A. Ulanowicz, S.A. Garmon, K.C. Grega, S.K. Hendges, D.S. Toops, C.W. Ford, G.E. Zurenko, Synthesis and antibacterial activity of U-100592 and U100766, two oxazolidinone antibacterial agents for the potential treatment of multidrug-resistant gram-positive bacterial infections, J. Med. Chem. 39 (1996) 673-679. 
[115] M.R. Barbachyn, C.W. Ford, Oxazolidinone structure-activity relationships leading to linezolid, Ang. Chem. Int. Ed. 42 (2003) 2010-2023.

[116] B. Pearlman, A. W. Perrault, R. M. Barbachyn, R. P. Manninen, R. D. Toops, S. D. Houser, J. T. Fleck, Process to prepare oxazolidinones, WO/1997/037980 (1997).

[117] Y. Zhang, K. Post-Martens, S. Denkin, New drug candidates and therapeutic targets for tuberculosis therapy, Drug Discov. Today 11 (2006) 21-27.

[118] J.W.C. Alffenaar, T. van der Laan, S. Simons, T.S. van der Werf, P.J. van de Kasteele, H. de Neeling, D. van Soolingen, Susceptibility of clinical Mycobacterium tuberculosis isolates to a potentially less toxic derivate of linezolid, PNU-100480, Antimicrob. Agents Chemother. 55 (2011) 1287-1289.

[119] L. Alcala, M.J. Ruiz-Serrano, C. Perez-Fernandez Turegano, D. Garcia de Viedma, M. Diaz-Infantes, M. Marin-Arriaza, E. Bouza, In vitro activities of linezolid against clinical isolates of Mycobacterium tuberculosis that are susceptible or resistant to first-line antituberculous drugs, Antimicrob. Agents Chemother. 47 (2003) 416-417.

[120] J.C. Rodríguez, M. Ruiz, M. López, G. Royo, In vitro activity of moxifloxacin, levofloxacin, gatifloxacin and linezolid against Mycobacterium tuberculosis, Int. J. Antimicrob. Agents 20 (2002) 464-467.

[121] M.H. Cynamon, S.P. Klemens, C.A. Sharpe, S. Chase, Activities of several novel oxazolidinones against Mycobacterium tuberculosis in a murine model, Antimicrob. Agents Chemother. 43 (1999) 1189-1191.

[122] R. Dietze, D.J. Hadad, B. McGee, LP.D. Molino, E.L.N. Maciel, C.A. Peloquin, D.F. Johnson, S.M. Debanne, K. Eisenach, W.H. Boom, M. Palaci, J.L. Johnson, Early and extended early bactericidal activity of linezolid in pulmonary tuberculosis, Am. J. Respir. Crit. Care Med. 178 (2008) 1180-1185.

[123] J. Fortun, P. Martin-Davila, E. Navas, M.J. Perez-Elias, J. Cobo, M. Tato, E.G.G. De la Pedrosa, E. Gomez-Mampaso, S. Moreno, Linezolid for the treatment of multidrug-resistant tuberculosis, J. Antimicrob. Chemother. 56 (2005) 180-185.

[124] I.N. Park, S.-B. Hong, Y.-M. Oh, M.-N. Kim, C.-M. Lim, S.D. Lee, Y. Koh, W.S. Kim, D.S. Kim, W.D. Kim, T.S. Shim, Efficacy and tolerability of daily-half dose linezolid in patients with intractable multidrug-resistant tuberculosis, J. Antimicrob. Chemother. 58 (2006) 701-704.

[125] G.F. Schecter, C. Scott, L. True, A. Raftery, J. Flood, S. Mase, Linezolid in the treatment of multidrug-resistant tuberculosis, Clin. Infect. Dis. 50 (2010) 49-55.

[126] M.R. Barbachyn, D.K. Hutchinson, S.J. Brickner, M.H. Cynamon, J.O. Kilburn, S.P. Klemens, S.E. Glickman, K.C. Grega, S.K. Hendges, D.S. Toops, C.W. Ford, G.E. Zurenko, Identification of a novel oxazolidinone (U-100480) with potent antimycobacterial activity, J. Med. Chem. 39 (1996) 680-685.

[127] K.N. Williams, C.K. Stover, T. Zhu, R. Tasneen, S. Tyagi, J.H. Grosset, E. Nuermberger, Promising antituberculosis activity of the oxazolidinone PNU-100480 relative to that of linezolid in a murine model, Antimicrob. Agents Chemother. 53 (2009) 1314-1319.

[128] K.N. Williams, S.J. Brickner, C.K. Stover, T. Zhu, A. Ogden, R. Tasneen, S. Tyagi, J.H. Grosset, E.L. Nuermberger, Addition of PNU-100480 to first-line drugs shortens the time needed to cure murine tuberculosis, Am. J. Respir. Crit. Care Med. 180 (2009) 371-376.

[129] PNU-100480 clinicaltrials.gov (NCT ID: NCT00871949 and NCT00990990).

[130] R.S. Wallis, W.M. Jakubiec, V. Kumar, A.M. Silvia, D. Paige, D. Dimitrova, X. Li, L. Ladutko, S. Campbell, G. Friedland, M. Mitton-Fry, P.F. Miller, Pharmacokinetics and whole-blood bactericidal activity against Mycobacterium tuberculosis of single doses of PNU-100480 in healthy volunteers, J. Infect. Dis. 202 (2009) 745-751.

[131] R.S. Wallis, W. Jakubiec, V. Kumar, G. Bedarida, A. Silvia, D. Paige, T. Zhu, M. Mitton-Fry, L. Ladutko, S. Campbell, P.F. Miller, Biomarker-assisted dose selection for safety and efficacy in early development of PNU-100480 for tuberculosis, Antimicrob. Agents Chemother. 55 (2011) 567-574.

[132] PNU-100480 clinicaltrials.gov (NCT ID: NCT01225640)

[133] AZD5847 clinicaltrials.gov (NCT ID: NCT01037725 and NCT01116258).

[134] V. Balasubramanian, S. Butler, AZD5847, WGND Annual Meeting, Lille, France (2011).

[135] R. Okumura, T. Hirata, Y. Onodera, K. Hoshino, T. Otani, T. Yamamoto, Dualtargeting properties of the 3-aminopyrrolidyl quinolones, DC-159a and sitafloxacin, against DNA gyrase and topoisomerase IV: contribution to reducing in vitro emergence of quinolone-resistant Streptococcus pneumoniae, J. Antimicrob. Chemother. 62 (2008) 98-104.

[136] Y, Onodera, T. Hirata, K. Hoshino, T. Otani, Dc-159a, A Novel Quinolone, Showed High Inhibitory Activity Against Altered Topoisomerases of Streptococcus Pneumonia and Mycobacterium Tuberculosis, Abstr. 47th Intersci. Conf. Antimicrob. Agents Chemother, American Society for Microbiology, Washington DC, 2007, abstr. F1-2126.

[137] J.-i. Sekiguchi, A. Disratthakit, S. Maeda, N. Doi, Characteristic resistance mechanism of Mycobacterium tuberculosis to DC-159a, a new respiratory quinolone, Antimicrob. Agents Chemother. 55 (2011) 3958-3960.

[138] A. Disratthakit, N. Doi, In vitro activities of DC-159a, a novel fluoroquinolone, against Mycobacterium Species, Antimicrob. Agents Chemother. 54 (2010) 2684-2686.
[139] N. Doi, A. Disratthakit, S. Ogiso, U. S., Y. Kurosaka, In vivo efficacy of DC-159a a new generation of respiratory quinolone, against experimental murine tuberculosis due to multi-drug-resistant Mycobacterium tuberculosis, Abstr. 46th Intersci. Conf. AntimIcrob. Agents Chemother, American Society for Microbiology, San Francisco., abstra. F1-0492 (2006).

[140] Z. Ahmad, A. Minkowski, C.A. Peloquin, K.N. Williams, K.E. Mdluli, J.H. Grosset, E.L. Nuermberger, Activity of the fluoroquinolone DC-159a in the initial and continuation phases of treatment of murine tuberculosis, Antimicrob. Agents Chemother. 55 (2011) 1781-1783.

[141] E. Bogatcheva, C. Hanrahan, P. Chen, J. Gearhart, K. Sacksteder, L. Einck, C. Nacy, M. Protopopova, Discovery of dipiperidines as new antitubercular agents, Bioorg. Med. Chem. Lett. 20 (2010) 201-205.

[142] E. Bogatcheva, C. Hanrahan, B. Nikonenko, G. de los Santos, V. Reddy, P. Chen, F. Barbosa, L. Einck, C. Nacy, M. Protopopova, Identification of SQ609 as a lead compound from a library of dipiperidines, Bioorg. Med. Chem. Lett. 21 (2011) $5353-5357$

[143] V. Makarov, G. Manina, K. Mikusova, U. Möllmann, O. Ryabova, B. SaintJoanis, N. Dhar, M.R. Pasca, S. Buroni, A.P. Lucarelli, A. Milano, E. De Rossi, M. Belanova, A. Bobovska, P. Dianiskova, J. Kordulakova, C. Sala, E. Fullam, P. Schneider, J.D. McKinney, P. Brodin, T. Christophe, S. Waddell, P. Butcher, J. Albrethsen, I. Rosenkrands, R. Brosch, V. Nandi, S. Bharath, S. Gaonkar, R.K. Shandil, V. Balasubramanian, T. Balganesh, S. Tyagi, J. Grosset, G. Riccardi, S.T. Cole, Benzothiazinones kill Mycobacterium tuberculosis by blocking arabinan synthesis, Science 324 (2009) 801-804.

[144] Z. Ge, R. Li, T. Cheng, An efficient synthesis of formylmethyl piperidine-1carbodithioate diethyl acetal and analogs, Synth. Commun. 29 (1999) 3191-3196.

[145] V. Makarov, U. Möllmann, S.T. Cole, New benzothiazinone derivatives and their use as antibacterial agents, WO2007134625 (2007)

[146] M.R. Pasca, G. Degiacomi, A.L.d.J. Ribeiro, F. Zara, P. De Mori, B. Heym, M. Mirrione, R. Brerra, L. Pagani, L. Pucillo, P. Troupioti, V. Makarov, S.T. Cole, G. Riccardi, Clinical isolates of Mycobacterium tuberculosis in four European hospitals are uniformly susceptible to benzothiazinones, Antimicrob. Agents Chemother. 54 (2010) 1616-1618.

[147] G. Manina, M. Bellinzoni, M.R. Pasca, J. Neres, A. Milano, A.L. De Jesus Lopes Ribeiro, S. Buroni, H. Škovierová, P. Dianišková, K. Mikušová, J. Marák V. Makarov, D. Giganti, A. Haouz, A.P. Lucarelli, G. Degiacomi, A Piazza, L.R. Chiarelli, E. De Rossi, E. Salina, S.T. Cole, P.M. Alzari, G. Riccardi, Biological and structural characterization of the Mycobacterium smegmatis nitroreductase $\mathrm{NfnB}$, and its role in benzothiazinone resistance, Mol. Microbiol. 77 (2010) 1172-1185.

[148] T. Christophe, M. Jackson, H.K. Jeon, D. Fenistein, M. Contreras-Dominguez J. Kim, A. Genovesio, J.-P. Carralot, F. Ewann, E.H. Kim, S.Y. Lee, S. Kang, M.J. Seo, E.J. Park, H. Škovierová, H. Pham, G. Riccardi, J.Y. Nam, L. Marsollier, M. Kempf, M.-L. Joly-Guillou, T. Oh, W.K. Shin, Z. No, U. Nehrbass, R. Brosch, S.T. Cole, P. Brodin, High content screening identifies decaprenylphosphoribose 2' epimerase as a target for intracellular antimycobacterial inhibitors, PLoS Pathog. 5 (2009) e1000645.

[149] P. Brodin, T. Christophe, High-content screening in infectious diseases, Curr. Opin. Chem. Biol. 15 (2011) 534-539.

150] J. Engohang-Ndong, D. Baillat, M. Aumercier, F. Bellefontaine, G.S. Besra, C. Locht, A.R. Baulard, EthR, a repressor of the TetR/CamR family implicated in ethionamide resistance in mycobacteria, octamerizes cooperatively on its operator, Mol. Microbiol. 51 (2004) 175-188.

[151] N. Willand, B. Dirie, X. Carette, P. Bifani, A. Singhal, M. Desroses, F. Leroux E. Willery, V. Mathys, R. Deprez-Poulain, G. Delcroix, F. Frenois, M. Aumercier, C. Locht, V. Villeret, B. Deprez, A.R. Baulard, Synthetic EthR inhibitors boost antituberculous activity of ethionamide, Nat. Med. 15 (2009) 537-544.

[152] W. Weber, R. Schoenmakers, B. Keller, M. Gitzinger, T. Grau, M. Daoud-El Baba, P. Sander, M. Fussenegger, A synthetic mammalian gene circuit reveals antituberculosis compounds, Proc. Natl. Acad. Sci. U S A 105 (2008) 9994-9998.

[153] D. Bonnel, R. Legouffe, N. Willand, A. Baulard, G. Hamm, B. Deprez, J. Stauber MALDI imaging techniques dedicated to drug-distribution studies, Bioanalysis 3 (2011) 1399-1406.

[154] M. Flipo, M. Desroses, N. Lecat-Guillet, B. Dirie, X. Carette, F. Leroux, C. Piveteau, F. Demirkaya, Z. Lens, P. Rucktooa, V. Villeret, T. Christophe, H.K. Jeon, C. Locht, P. Brodin, B. Deprez, A.R. Baulard, N. Willand, Ethionamide boosters: synthesis, biological activity, and structure-activity relationships of a series of 1,2,4-oxadiazole EthR inhibitors, J. Med. Chem. 54 (2011) 2994-3010.

[155] M. Flipo, M. Desroses, N. Lecat-Guillet, B. Villemagne, N. Blondiaux, F. Leroux C. Piveteau, V. Mathys, M.-P. Flament, J. Siepmann, V. Villeret, A. Wohlkönig, R. Wintjens, S.H. Soror, T. Christophe, H.K. Jeon, C. Locht, P. Brodin, B. Deprez A.R. Baulard, N. Willand, Ethionamide boosters. 2. Combining bioisosteric replacement and structure-based drug design to solve pharmacokinetic issues in a series of potent 1,2,4-oxadiazole EthR inhibitors, J. Med. Chem. 55 (2012) 68-83. 